\title{
Mitochondrial Calcium Uniporter Structure and Function in Different Types of Muscle Tissues in Health and Disease
}

\author{
Nadezhda V. Tarasova ${ }^{1, *}$, Polina A. Vishnyakova ${ }^{2}$ (D), Yulia A. Logashina ${ }^{1,3}$ \\ and Andrey V. Elchaninov 2,4,5 \\ 1 Institute of Molecular Medicine, Sechenov First Moscow State Medical University, Trubetskaya str. 8, bld. 2, \\ Moscow 119991, Russia; yulia.logashina@gmail.com \\ 2 National Medical Research Center for Obstetrics, Gynecology and Perinatology Named after Academician \\ V.I. Kulakov of Ministry of Healthcare of Russian Federation, 4 Oparina Street, Moscow 117997, Russia; \\ vpa2002@mail.ru (P.A.V.); elchandrey@yandex.ru (A.V.E.) \\ 3 Shemyakin-Ovchinnikov Institute of Bioorganic Chemistry, Russian Academy of Sciences, \\ Miklukho-Maklaya Street 16/10, Moscow 117997, Russia \\ 4 Scientific Research Institute of Human Morphology, 3 Tsurupa Street, Moscow 117418, Russia \\ 5 Peoples' Friendship University of Russia, 6 Miklukho-Maklaya Street, Moscow 117198, Russia \\ * Correspondence: compasstar@gmail.com; Tel.: +7-495-609-1400
}

Received: 14 August 2019; Accepted: 26 September 2019; Published: 28 September 2019

check for updates

\begin{abstract}
Calcium ions $\left(\mathrm{Ca}^{2+}\right)$ influx to mitochondrial matrix is crucial for the life of a cell. Mitochondrial calcium uniporter $(\mathrm{mtCU})$ is a protein complex which consists of the pore-forming subunit (MCU) and several regulatory subunits. $\mathrm{MtCU}$ is the main contributor to inward $\mathrm{Ca}^{2+}$ currents through the inner mitochondrial membrane. Extensive investigations of $\mathrm{mtCU}$ involvement into normal and pathological molecular pathways started from the moment of discovery of its molecular components. A crucial role of $\mathrm{mtCU}$ in the control of these pathways is now recognized in both health and disease. In particular, impairments of $\mathrm{mtCU}$ function have been demonstrated for cardiovascular and skeletal muscle-associated pathologies. This review summarizes the current state of knowledge on mtCU structure, regulation, and function in different types of muscle tissues in health and disease.
\end{abstract}

Keywords: calcium; calcium signaling; mitochondrial calcium uniporter; calcium homeostasis; regulatory pathways; myocardium; skeletal muscle; smooth muscle

\section{Introduction}

Calcium ions $\left(\mathrm{Ca}^{2+}\right)$ are indispensable for signal transduction and regulation of target cell activity. Mitochondria are widely recognized as one of the key organelles maintaining $\mathrm{Ca}^{2+}$ homeostasis $[1,2]$. In mitochondrial matrix, $\mathrm{Ca}^{2+}$ stimulates mitochondrial activity, metabolism, and energy production, thus allowing the cells to adapt to immediate metabolic needs [3]. On the other hand, the mitochondrial $\mathrm{Ca}^{2+}$ buffer prevents the excessive increase in metabolism induced by $\mathrm{Ca}^{2+}$ stimulation [4]. In addition to its influence on bioenergetics, mitochondrial $\mathrm{Ca}^{2+}$ plays an important role in the regulation of various aspects of the cell life from contractility [5], chemotaxis, and migration [6,7] to reactive oxygen species (ROS) production [8], cell cycle and proliferation, the mitochondrial permeability transition pore (mPTP) opening, and cell death [9-11].

Since $\mathrm{Ca}^{2+}$ is a universal second messenger, the mitochondrial $\mathrm{Ca}^{2+}$ homeostasis is affected in various pathologies. Indeed, alterations in mitochondrial $\mathrm{Ca}^{2+}$ handling were observed in a range of cancers [4,12], as well as cardiovascular [13] and neurodegenerative [14] diseases. 
$\mathrm{Ca}^{2+}$ penetrates through the outer mitochondrial membrane via a voltage-dependent anion channel (VDAC) [15]. The mitochondrial $\mathrm{Ca}^{2+}$ uniporter ( $\mathrm{mtCU}$ ), located in the inner mitochondrial membrane, unequivocally represents the dominant mechanism of $\mathrm{Ca}^{2+}$ transport from intermembrane space to mitochondrial matrix, although several $\mathrm{mtCU}$-independent mechanisms were identified as well [16]. $\mathrm{Ca}^{2+}$ efflux from mitochondria occurs via $\mathrm{Na}^{+} / \mathrm{Ca}^{2+}$ and $\mathrm{H}^{+} / \mathrm{Ca}^{2+}$ exchangers [1].

In this review, we discuss the most recent discoveries on the molecular structure of $\mathrm{mtCU}$ and the regulatory mechanisms underlying its activity in connection with its function in different types of muscle tissue under normal physiological conditions and in pathology.

\section{Structural and Electrophysiological Characteristics of MtCU}

MtCU consists of at least four main components: The pore-forming subunit (MCU) capable of higher-order oligomerization, the essential MCU regulator (EMRE), and two membrane gate-keeping factors (MICU1 and MICU2) (Figure 1) [17,18]. The summer of 2018 could rightly be called the season of cryo-electron microscopy (cryo-EM) for $\mathrm{mtCU}$, since three significant works on its structure were published at this time [19-21]. Two years earlier, a core region of MCU was determined using nuclear magnetic resonance (NMR) by Oxenoid et al. [17]. MCU forms an elongated tetramer where each of the four protomers consists of three structural domains: Hydrophobic transmembrane domain (TMD), mainly located in the inner membrane; $\mathrm{N}$-terminal domain (NTD) and coiled-coil domain (CCD), jointly forming a large hydrophilic region located in the mitochondrial matrix [19]. TMD is formed by two helices (TM1, TM2) which play a major role in the $\mathrm{mtCU}$ architecture: TM1 is essential for the interaction with EMRE while TM2 forms the central ion conduction pore [21]. A highly-conserved sequence motif W-D- $\Phi-\Phi-E-P-V-T-Y(\Phi$ stands for a hydrophobic amino acid) is located in the $\mathrm{N}$-terminal region of TM2. The Asp and Glu residues in this motif from each of the four protomers form two acidic rings in the channel pore and has been proposed to constitute the selective $\mathrm{Ca}^{2+}$ filter $[17,22-24]$. Human MCU also contains the linker helix domain (LHD) that links the NTD and CC1 helix of CCD. In human MCU, the Asp and Glu residues in the W-D-I-M-E-P sequence motif (denoted as "DIME sequence") are also involved in the formation of two rings of acidic residues for the selective $\mathrm{Ca}^{2+}$ permeation $[18,25]$.

MtCU had been identified as a highly selective $\mathrm{Ca}^{2+}$ channel in the mitochondrial inner membrane long before its molecular nature was determined $[12,26,27]$. Nevertheless, the data on the electrophysiological properties of $\mathrm{mtCU}$ are rather heterogeneous and sometimes controversial. Whereas mtCU currents recorded in recombinant MCU-MICU1 [28] and MCU-EMRE [29] complexes in the planar lipid bilayers differ several times, data from whole mitoplasts differ by two orders [30,31]. To overcome the complexity of mitoplasts technique, a system based on Xenopus oocytes with the human MCU-EMRE complex targeted to the plasma membrane has been recently established [32]. Complex expression was confirmed by inhibitory analysis of inward $\mathrm{Ca}^{2+}$ current with mtCU selective inhibitor Ru360 [32]. Although this system can be considered as a promising tool for electrophysiological analysis both to determine fundamental molecular mechanisms and to test new potential pharmacological modulators, the reported mtCU-current parameters would require additional validation before the introduction of the model to applied research.

$\mathrm{MtCU}$ is better investigated as the assembled complex rather than individual subunits. This circumstance, however, does not interfere with effective simulation of the mtCU activity. Wacquier et al. introduced the computational model based on experimental data, which successfully described $\mathrm{Ca}^{2+}$ kinetics in either a suspension of mitochondria isolated from hepatocytes or the mitochondria in intact hepatocytes and, importantly, accounted for the difference between these two systems [33]. In addition, they analyzed the $\mathrm{Ca}^{2+}$ currents with consideration of the mitochondrial heterogeneity: The authors assumed that the total mitochondrial volume might correspond to different numbers of individual mitochondria. This consideration is important because the $\mathrm{Ca}^{2+}$ influx strongly correlates with the level of MCU expression and protein abundance in individual organelles. Despite the availability of the experimental data sufficient to create a computer model of $\mathrm{Ca}^{2+}$ currents via $\mathrm{mtCU}$, 
many questions about the structure and mutual orientation of the subunits in the complex are still unclear. Next, we will focus on the structural and regulatory features of the human mtCU components.

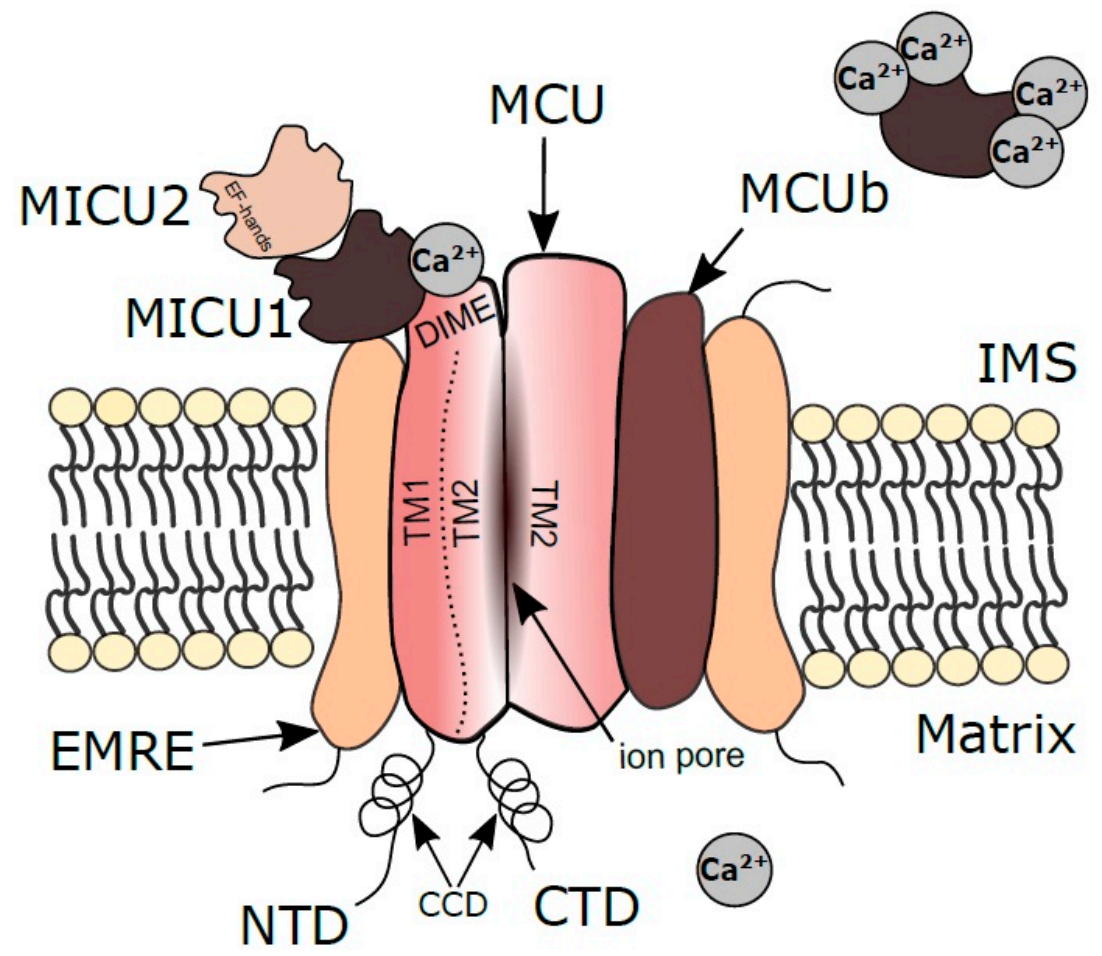

Figure 1. Scheme of mtCU structure. Mitochondrial calcium uniporter pore-forming subunit (MCU) and regulatory subunits are shown: MICU1 and 2-mitochondrial calcium uptake 1 and 2; MCUb-mitochondrial calcium uniporter dominant negative beta subunit; EMRE-essential MCU regulator. IMS - intermembrane space; NTD—N-terminal domain; CTD—C-terminal domain; TM1, TM2 - two helices of the transmembrane domain; CCD—coiled coil domain; DIME—amino acids sequence mediating a $\mathrm{Ca}^{2+}$-modulated electrostatic interaction between MCU and MICU1. EF hand-helix-loop-helix structural motif of calcium-binding proteins MICU1 and MICU2. Modified from 10.1038/s41598-019-41996-3 under CC-BY.

\section{1. $M C U$}

The human MCU monomer consists of 351 amino acids and weighs about $40 \mathrm{kDa}$. Most of the data on the MCU tetramer structure is obtained by the cryo-EM approach and is particularly related to the structural features of the pore-forming tetramer channel discussed above. In this section, we will consider structural features and the role of extra-membrane parts of the tetramer in the functional activity of the whole complex. The matrix part of the tetramer protrudes $70 \AA$ from the membrane [20], and has four "legs" extending from TMDs, formed by parts of NTD, CCD, and LHD (in the case of humans) [18]. The space between the legs allows the ions to diffuse into the matrix after passing through the pore [20]. The $\mathrm{N}$-terminal matrix domain of human MCU consists of a conserved $\beta$-grasp-like fold containing a high-density cluster of negatively charged residues, the so-called MCU-regulating acidic patch (MRAP) [34]. Interaction of these residues with divalent cations $\left(\mathrm{Ca}^{2+}\right.$ or $\left.\mathrm{Mg}^{2+}\right)$ destabilizes the tetramer toward monomer, thus causing inhibition of the $\mathrm{mtCU}$ activity in response to $\mathrm{Mg}^{2+}$ and $\mathrm{Ca}^{2+}$ binding [34].

Another structural feature of MCU is post-translational modifications which affect the functional activity of the protein. Cys is highly sensitive amino acid incorporated into proteins in the thiol (R-SH) form, which subsequently becomes oxidized or converted into disulfides (R-S-S-R). The post-translational modifications of Cys include disulfide formation, S-glutathionylation, S-nitrosylation, persulfidation, etc [35]. Its pronounced oxidizability makes Cys a redox-sensor 
in the cell. Dong et al. identified a conserved cysteine at position 97 in the MCU's NTD as a reactive thiol susceptible to S-glutathionylation upon oxidative stress. The authors found that the MCU oxidation promotes the MCU higher-order oligomer formation while increasing the rates of $\mathrm{Ca}^{2+}$ uptake, elevating mitochondrial concentrations of ROS, and enhancing the $\mathrm{Ca}^{2+}$-induced cell death [35]. NTD is also involved in the interaction of MCU with Miro1, the outer mitochondrial membrane protein important for mitochondrial movement. Niescier et al. revealed specific interaction of Miro1 with the MCU's NTD and considered it as a link in novel mechanism modulating the mitochondrial $\mathrm{Ca}^{2+}$ uptake and mitochondrial transport [36].

The opposite part of the MCU tetramer faces the intermembrane space and acts as an important site of interaction with the MICU1 regulatory subunit, although whether this interaction occurs inside the membrane or in the intermembrane space is still debatable. As recently shown by Phillips et al., Asp in the MCU's DIME sequence mediates $\mathrm{Ca}^{2+}$-modulated electrostatic interaction with MICU1 [24]. In the absence of $\mathrm{Ca}^{2+}$, MICU1 binds to DIME with two arginines and blocks the intermembrane space entrance of the MCU pore. In the presence of $\mathrm{Ca}^{2+}$, its ions bind to MICU1 and disrupt this interaction, leading to the pore opening [24,37]. Importantly, MICU1 expression is related to MCU level, and the ratio of MICU1 and MCU protein levels positively correlates with their binding, which indicates the importance of the $\mathrm{Ca}^{2+}$ threshold for $\mathrm{Ca}^{2+}$ uptake and cooperativity of the whole mtCU complex [38].

\section{2. $M C U b$}

$\mathrm{MCUb}$ is a protein of 336 amino acids and has a molecular weight of about $40 \mathrm{kDa}$ (similar to $\mathrm{MCU}$ ). The sequence identity between MCUb and MCU is $48.77 \%$ (according to BLAST). MCUb alone is incapable of forming a $\mathrm{Ca}^{2+}$-conductive channel but plays an important role in the regulation of $\mathrm{mtCU}$ functional activity by forming heteromers with MCU $[39,40]$. An increase in the MCUb-to-MCU ratio has been shown to reduce the activity of $\mathrm{MCU}$; thus, $\mathrm{MCUb}$ acts as a dominant-negative subunit that attenuates the $\mathrm{Ca}^{2+}$ currents via the channel [39].

\subsection{MICU1}

The regulatory subunit MICU1 consists of 476 amino acids and weighs about $54 \mathrm{kDa}$. As we have already mentioned, MICU1 binds with MCU through the DIME sequence thus serving as a gatekeeper of mtCU [37,41]. At low $\mathrm{Ca}^{2+}$ concentrations, MICU1 inhibits the $\mathrm{Ca}^{2+}$ current; at high $\mathrm{Ca}^{2+}$ concentrations, the MCU-binding site in MICU1 is blocked by $\mathrm{Ca}^{2+}$ ions and the pore conductance is restored. MICU1 is able to form a homodimer or heterodimer (by disulfide bonds) with another regulatory subunit-MICU2. Both MICU1 and MICU2 have high affinities for $\mathrm{Ca}^{2+}$ [42]. When a heterodimer is formed, the $\mathrm{Ca}^{2+}$ binding capacity of individual subunits (in the nanomolar range of concentrations) is preserved. As demonstrated by Kamer et al., the MICU1-MICU2 heterodimer selectively binds with liposomes containing cardiolipin; this finding suggests a mechanism for association of the complex with the inner mitochondrial membrane [42].

MICU1 has two structural domains separated by a long alpha helix [42]. Each domain contains a helix-loop-helix structural motif, the so-called EF-hand, typical for $\mathrm{Ca}^{2+}$-binding proteins. This motif is especially important for overall ion selectivity of the uniporter. Kamer et al. have suggested that specific metal-ligand interactions in EF-hand underlie the ability of MICU1 to differentiate between $\mathrm{Ca}^{2+}$ and $\mathrm{Mn}^{2+}$ [43]. According to their model, at high $\mathrm{Ca}^{2+}$ levels, $\mathrm{Ca}^{2+}$ binds to EF hands promoting the channel opening and facilitating the passage of $\mathrm{Ca}^{2+}$ and $\mathrm{Mn}^{2+}$ through the pore. When manganese level is high and $\mathrm{Ca}^{2+}$ is low, $\mathrm{Mn}^{2+}$ binds to the MICU1's EF-hands without structural changes in the MICU1-MCU interconnection and the pore remains closed. In MICU1 knockout cells (HEK-293T), MCU has no such ion selectivity, which leads to $\mathrm{Mn}^{2+}$ loading in mitochondria. Wettmarshausen et al. came to a similar conclusion: Co-expression of MCU and MICU1 in the yeast S. cerevisiae as a model system protects the cells against the uniporter-dependent $\mathrm{Mn}^{2+}$ overload and $\mathrm{Mn}^{2+}$ toxicity [44]. 
In vivo deletion of MICU1 leads to and larval lethality in Drosophila [45], while in mice causes $\mathrm{Ca}^{2+}$ overload, severe neurological and myopathic defects, similar to that observed in MICU1-deficient patients [41].

MICU1 degradation is Parkin-mediated and occurs in proteasome. Interestingly, it proceeds independently of the E3-ubiquitin ligase activity of Parkin protein but depends on its Ubl-domain [46]. Parkin is therefore considered as a regulator of $\mathrm{mtCU}$ composition and activity.

MICU1.1 is a splicing isoform of MICU1 having an extra micro-exon between exons 5 and 6, which encodes four amino acids and is highly conserved among all vertebrates [47]. MICU1.1 is expressed in skeletal muscle and at a lower level in the brain, and nowhere else, whereas the MICU1 expression is ubiquitous. All in all, MICU1.1 acts as an alternative regulator of mtCU in certain tissues; its function is believed to be related to the fast muscle contraction.

\subsection{MICU2}

MICU2, another gatekeeper, contains 434 amino acids and has a molecular weight of about $50 \mathrm{kDa}$. Kamer et al. [48] recently revealed the presence of two structural lobes in murine MICU2 protein, with a pair of EF-hands each, described essential structural differences in N- and C-terminal segments between MICU2 and MICU1, and also proposed computational models for participation of the MICU1-MICU2 complex in gating mechanisms of the uniporter. Human MICU2 dimerizes in $\mathrm{Ca}^{2+}$ concentration-dependent manner in two types of dimers: Back-to-back or face-to-face dimers. At low $\mathrm{Ca}^{2+}$ levels, MICU2 forms back-to-back homodimers thus blocking the $\mathrm{Ca}^{2+}$ conduction through the pore, while at high $\mathrm{Ca}^{2+}$ levels both MICU2 and MICU1 form face-to-face dimers which do not interfere with $\mathrm{Ca}^{2+}$ currents [49]. Payne et al. showed that at low $\mathrm{Ca}^{2+}$ concentrations MICU1 mainly performs the gatekeeping function, while MICU2 modulates its inhibitory effect on mtCU [50]. Despite the seemingly subordinate role of MICU2 in the regulation of $\mathrm{Ca}^{2+}$ currents, depletion of MICU2 decreases the levels of both MCU and MICU1 proteins without altering transcription of the corresponding genes [51]. MICU2 null mutations in patients lead to neurodevelopmental complications, including gliosis, periventricular haemorrhage, sagittal sinus thrombosis, periventricular encephalomalacia, and cognitive impairment [52]. Disruptions in $\mathrm{Ca}^{2+}$ homeostasis persisting in the patients' cells: The MICU2-deficient cells exhibited mitochondrial $\mathrm{Ca}^{2+}$ overload at resting state and showed a slower bradykinin-stimulated $\mathrm{Ca}^{2+}$ influx than control cells from healthy individuals [52].

\subsection{MICU3}

MICU3 contains 530 amino acids and weighs about $60 \mathrm{kDa}$. According to UNIProt database, the MICU3 structure also has the EF-hand motif (as in MICU1 and MICU2), and its presence in skeletal muscle has been reported [53]. In earlier studies, MICU3 was considered as a regulatory subunit with gatekeeping function (similarly with MICU1 and MICU2) [49]. However, MICU3 has been recently shown to form heterodimers with MICU1 but not with MICU2 or itself, with prevalent expression of MICU3 in brain tissue [54]. Stimulation of MICU3-overexpressing HeLa cells with agonists (e.g., ATP) led to increased mitochondrial $\mathrm{Ca}^{2+}$ uptake rates. All in all, MICU3 is presently considered as mtCU activator with reduced gatekeeping function [54]. The presence of additional brain-specific $\mathrm{mtCU}$ regulators may be related to fine-tuning of $\mathrm{Ca}^{2+}$ signals in neuronal networks.

\section{6. $E M R E$}

EMRE, also known as SMDT1, is a 107 amino acids protein weighing about $11 \mathrm{kDa}$. It contains a TMD while its $\mathrm{N}$ - and $\mathrm{C}$ - terminal domains are exposed to the matrix and intermembrane space, respectively $[18,55,56]$. A set of acidic residues exposed to mitochondrial matrix works as a $\mathrm{Ca}^{2+}$ sensor [57]. EMRE is only found in metazoans, and cryo-EM structural analysis of human MCU-EMRE complex demonstrated that each EMRE molecule binds to one MCU protomer, with the resulting architecture of the MCU-EMRE tetramer working as a minimal functional mtCU complex [18]. Without MCU, EMRE is ineffective and insufficient for $\mathrm{Ca}^{2+}$ uptake [55,58]. It is now clearly evident that EMRE 
provides both physical interconnection of MICU1 and MICU2 with MCU and stabilizes the entire $\mathrm{Ca}^{2+}$ pore in open state with $\beta$-hairpin in its $\mathrm{N}$-domain [18,56]. EMRE participates not only in the regulation of single uniporters, but also in the functional coupling and coordination between several mtCU complexes [18]. Thus, EMRE is considered as a stabilizer of the MCU interaction with other regulatory subunits and a major regulator of $\mathrm{mtCU}$ cooperativity.

\subsection{MCUR1}

MCUR1 contains 359 amino acids and weighs about $40 \mathrm{kDa}$. MCUR1 is a regulatory protein which is often overlooked in the context of mtCU functioning. Orthologs of MCUR1 are found in various organisms, but whether to accept MCUR1 as an independent and separate subunit is still questionable. The published data indicates that MCUR1 deletion significantly impairs $\mathrm{Ca}^{2+}$ uptake; therefore, MCUR1 may be considered as a positive regulator of mtCU complex [59]. Structurally, human MCUR1 has several domains: A head, a $\beta$-layer neck and a stalk, set side by side in the matrix, and a transmembrane domain [60]. The head domain of MCUR1 directly contacts the NTD of MCU, and MCUR1 function is controlled proteolytically [59-61]. Tissue-specific MCUR1 knockout (KO) in cardiac muscle- and endothelium lead to decreased ATP levels, impaired mitochondrial $\mathrm{Ca}^{2+}$ import, and increased autophagy in cardiomyocytes and endothelial cells [59]. MCUR1 also plays the essential role in the forming EMRE-MCU complex: In addition to its interaction with MCU, MCUR1 could directly interact with EMRE thereby providing a link to the full assembly complex. Up-regulated expression of MCUR1 was observed in a pathological condition: MCUR1 promoted the epithelial-mesenchymal transition of hepatocellular carcinoma cells followed by invasion and metastasis [62].

\section{MtCU Regulation by Intracellular Signaling Pathways}

The proper mitochondrial $\mathrm{Ca}^{2+}$ handling, provided by proper mtCU functioning, is essential for the well-being of individual cells and the whole organism. Fine-tuning of mtCU function is carried out at multiple levels, including transcriptional, post-transcriptional, and post-translational levels [63]. Several transcriptional regulators of mtCU are known, and most likely there are more of them to be described. The cyclic AMP response element-binding protein (CREB) was the first identified transcriptional factor regulating MCU expression [64]. Shanmughapriya et al. discovered a direct interaction of activated CREB with an MCU promoter stimulating the gene expression. The important point is that cytoplasmic $\mathrm{Ca}^{2+}$ signals induce $\mathrm{CREB}$ activation through its phosphorylation by various kinases. Damping of $\mathrm{Ca}^{2+}$ oscillations reduces CREB phosphorylation leading to significantly lower MCU expression [64]. Recently, the same group revealed downregulation of MICU1 expression by transcription factor Foxd1 in human induced pluripotent stem cells (hiPSCs) under glycolytic and hypoxic conditions. Foxd1 knockdown and the consequent MICU1 upregulation turned out to be necessary for the periodic cytosolic $\mathrm{Ca}^{2+}$ oscillations essential for cell differentiation and maturation [65].

Post-transcriptional regulation of $\mathrm{mtCU}$ expression and function by microRNAs (miRs) is not yet fully understood, although the influence of miRs on mitochondrial $\mathrm{Ca}^{2+}$ was recently reviewed [66]. Remarkably, all miRs, identified as mtCU regulators, reduce the MCU subunit expression, but the overall physiological effect depends on tissue type and other conditions. Indeed, miR-340 negatively regulates MCU expression and suppresses breast cancer metastasis [67]. At the same time, miR-25 overexpression in colon cancer ultimately resulted in decreased MCU protein expression providing protective anti-apoptotic effects and promoting cancer cells survival [68]. In the pulmonary arterial hypertension, miRs 25 and 138 cooperatively cause an impairment of mtCU function [69]. More specifically, simultaneous upregulation of miR-25 and miR-138 not only downregulates MCU transcription, but also inhibits MCU expression by means of binding with 3 '-untranslated region of MCU transcripts. The reciprocally increased MICU1 expression further enhances the mtCU dysfunction. On the other hand, downregulation of these miRs or restoration of mtCU function accordingly restores the $\mathrm{Ca}^{2+}$ homeostasis [69]. It should be noted that some authors consider pulmonary arterial hypertension as a cancer-like disease [70], and a shared miR-dependent mechanism promoting both 
cancer and pulmonary arterial hypertension progression would support this theory. Surprisingly, the oxidative stimulation-induced miR-25 elevation inhibits MCU expression in cardiomyocytes, thus being cytoprotective [71]. The MCU protein expression in myocardium is also selectively repressed by miR-1 [72], the most abundant miR in the heart, belonging to the "myomiR" family with muscle-specific expression and recognized for the central regulatory role in muscle biology [73]. MiR-1 targets the MCU $3^{\prime}$-untranslated region and causes a marked reduction in the MCU protein content, while the MCU mRNA level remains unchanged. Consistently, miR-1 overexpression significantly reduced the amplitude of the steady-state mitochondrial $\mathrm{Ca}^{2+}$ level in cardiomyocytes during pacing and suppressed the hypertrophic gene expression program. The beta-adrenergic receptor/Akt/FOXO axis was proposed as an upstream regulator of miR-1/MCU pathway [72]. DRP1 protein, responsible for mitochondrial fission, was also proposed as an upstream regulator of miR1-mtCU cascade by some authors [74], indicating interconnection of some pathways at the point of mtCU.

At the post-translational level of regulation, $\mathrm{mtCU}$ undergoes a variety of modifications including phosphorylation, S-glutathionylation, and methylation. It is now accepted that bioenergetic, oxidative, and $\mathrm{Ca}^{2+}$ pathways meet and regulate each other in mitochondria [8]. For this reason, the proteins involved in calcium handling and signaling require redox-sensors. In cell models of inflammation and hypoxia, the concomitant oxidative stress-induced S-glutathionylation of MCU leads to more prominent $\mathrm{MCU}$ oligomerization, an increase in mitochondrial $\mathrm{Ca}^{2+}$ uptake and ROS production, and, finally, cell death induced by the $\mathrm{Ca}^{2+}$ overload [35].

Phosphorylation of MCU by proline-rich tyrosine kinase 2 (Pyk2) after adrenoceptor stimulation in intact cardiac H9c2 myoblasts has been reported [75]. Adrenoceptor stimulation causes translocation of Pyk2 to mitochondrial matrix where Pyk2 directly phosphorylates MCU tyrosine residue(s), promoting MCU oligomerization into functional tetrameric MCU channels. The enhanced mitochondrial $\mathrm{Ca}^{2+}$ uptake via mtCU results in increased generation of ROS as well as calcium overload and initiation of the apoptotic signaling [75]. Similar activation of the Pyk2/MCU pathway accompanied by mitochondria damage and an increase in apoptosis was recently detected in the ischemic rat brain after middle cerebral artery occlusion, indicating that the Pyk2/MCU pathway may be a universal mediator of stress-induced mitochondrial damage and cell death [76].

Although direct phosphorylation of MCU by CaMKII in cardiac muscle was demonstrated, its relevance is still debatable. In 2012, Joiner et al. [30] published impressive data indicating the anti-ischemic effect of CaMKII inhibition with a transgenic mitochondrial-targeted inhibitory protein. The inhibition attenuated mitochondrial disruption, caused by ischemia and reperfusion, and protected cardiomyocytes from apoptosis, providing a significant decrease in the ischemic lesion area in myocardium. Physical association of CaMKII and mtCU was proved by their co-immunoprecipitation from the myocardial mitochondrial lysate, and the candidate phosphorylation sites in MCU were identified [30]. However, the electrophysiological data indicating that CaMKII promotes the mPTP opening and myocardial tissue death by increasing the mtCU current were not confirmed in more recent studies by other groups [31,77]. Furthermore, no functional change in the mtCU current after CaMKII application was observed, which suggests the lack of mtCU regulation by CaMKII [31]. The latest work of Nickel et al. provides comprehensive assessment of CaMKII role in the control of mitochondrial $\mathrm{Ca}^{2+}$ uptake, respiration, and ROS production during $\beta$-adrenergic stimulation and pacing in cardiomyocytes and isolated cardiac mitochondria from the CaMKII knockout mice. The authors pointed out that the results were inconsistent with any relevant role of CaMKII in the control of mitochondrial $\mathrm{Ca}^{2+}$ uptake [77]. It is also noteworthy that Nickel et al. failed to reproduce the experiments of Joiner et al. on isolated hearts as well as the CaMKII/mtCU co-immunoprecipitation. Therefore, the role of CaMKII in the recovery after ischemia-reperfusion injury in vivo and the direct interaction of CaMKII with mtCU in cardiac muscle are still questionable. Interestingly, the mtCU phosphorylation by CaMKII at the highly conserved Ser92 $[30,78]$ stimulates mitochondrial $\mathrm{Ca}^{2+}$ uptake which further activates the CaMKII-mediated $\mathrm{mtCU}$ phosphorylation thus forming a positive feedback 
circuit, and triggers migration of vascular smooth muscle cells (VSMCs) [79]. This observation brings up the matter of tissue-specific $\mathrm{mtCU}$ regulation and may encourage further studies in this direction.

Mitosis-specific phosphorylation of MCU by AMPK, necessary for the restoration of ATP levels during cell division, was recently reported [80]. The AMPK-dependent MCU phosphorylation at Ser57 activates the mitochondrial $\mathrm{Ca}^{2+}$ entry leading to the intensification of mitochondrial respiration and energy production necessary for the proper spindle dynamics [80]. The receptor-interacting protein kinase 1 (RIPK1), taking part in cell survival/apoptosis pathways, was recently shown to bind MCU for the mitochondrial $\mathrm{Ca}^{2+}$ uptake induction and thus contribute to the development of colorectal cancer [81]. Zeng et al. elucidated a RIPK1-MCU physical interaction in colorectal cancer samples from patients and HT29 cells using co-immunoprecipitation and confocal microscopy. The authors also identified Lys377, a known ubiquitination site, as crucial for the RIPK1 interaction with MCU. Unfortunately, this study provides no information regarding the specific phosphorylation site in MCU [81].

The large body of data on the mtCU regulation, obtained from cancer cells and models, are highly relevant for the search of new therapies along with the general understanding of $\mathrm{mtCU}$ regulation and functioning. For instance, a recently described Akt kinase-mediated phosphorylation of MICU1 at the N-terminal region in cancer is the first demonstration of a phosphorylation event for the MICU1 subunit [82]. More specifically, the mitochondrial pool of active Akt is responsible for the MICU1 phosphorylation at Ser124, which affects the MICU1 processing and results in the MICU1-MICU2 dimer instability. The loss of the MICU1 inhibitory influence on mtCU leads to a significant increase in the basal $\mathrm{Ca}^{2+}$ level in the mitochondrial matrix, culminating in the ROS production and tumor progression [82]. A more comprehensive functional evaluation of this MICU1 modification under normal and pathological conditions would be relevant.

In addition to phosphorylation, the MICU1 gatekeeper function is also modulated post-translationally through its methylation by arginine methyl transferase 1 (PRMT1) at Arg455 [83]. Interestingly, although the methylation of MICU1 desensitized it for $\mathrm{Ca}^{2+}$ and reduced the mitochondrial $\mathrm{Ca}^{2+}$ uptake, UCP2 was shown to bind exclusively to the methylated form and to restore the mitochondrial $\mathrm{Ca}^{2+}$ uptake in the cells with pronounced PRMT1 activity [83]. Although the early data on the UCP2/3 engagement in the regulation of $\mathrm{Ca}^{2+}$ uptake through the inner mitochondrial membrane were contradictory $[84,85]$, more recent studies have confirmed the regulatory effect of UCPs on mtCU [86,87].

Proper mitochondrial functioning requires the tightly controlled turnover of mitochondrial proteins. In particular, the mtCU assembly dynamics is maintained by m-AAA metalloproteases (ATPases associated with diverse cellular activities) [88]. Mitochondrial m-AAA proteases AFG3L2 and SPG7 rapidly digest the unassembled EMRE; however, after the EMRE incorporation into mtCU, its turnover is substantially inhibited. The excessive EMRE expression leads to the paradoxical $\mathrm{Ca}^{2+}$ leakage into mitochondria through the constitutively active MCU-EMRE subcomplex and the increased rates of $\mathrm{Ca}^{2+}$ uptake [89]. On the other hand, AFG3L2 loss leads to the facilitated mitochondrial $\mathrm{Ca}^{2+}$ overload followed by mPTP opening and neuronal death in murine model [90]. Interestingly, the functional loss of SPG7 led to similar changes, while physical loss was characterized by lower basal levels of mitochondrial $\mathrm{Ca}^{2+}$ and the increased $\mathrm{Ca}^{2+}$ retention capacity [91]. Considerably increased EMRE protein content and other major alterations in the $\mathrm{mtCU}$ stoichiometry and assembly observed in SPG7 KO cells [91]. At the body level, the SPG7 null mutation in Drosophila model caused shortened lifespan, progressive locomotor defects, increased sensitivity to chemical and environmental stress, and muscular and neuronal degeneration [92].

Summing up, these data indicate that mitochondrial $\mathrm{Ca}^{2+}$ uptake through $\mathrm{mtCU}$ is precisely regulated at multiple levels. Several health disorders associated with disturbances in mtCU functioning and involving different types of muscle tissues are discussed in upcoming sections. 


\section{The Role of MtCU in Cardiac Muscle}

\subsection{MtCU in Normal Myocardium Function}

Main function of the heart is to ensure blood supply to all organs and tissues. To provide it, myocardium undergoes constant rhythmic cycles of excitation followed by contraction (excitation-contraction coupling) based on the permanent $\mathrm{Ca}^{2+}$ release/uptake cycles in the cytoplasm and buffering organelles of cardiomyocytes [93]. Interestingly, in cardiomyocytes, the removal of $\mathrm{Ca}^{2+}$ from the cytoplasm after myocardial contraction is mostly provided by activities of the $\mathrm{Na}+/ \mathrm{Ca}^{2+}$ exchanger (NCX) in sarcolemma and the sarcoplasmic/endoplasmic reticulum $\mathrm{Ca}^{2+}$ ATPase (SERCA), whereas in non-muscle cells the $\mathrm{Ca}^{2+}$ buffering and termination of cytosolic $\mathrm{Ca}^{2+}$ signals mostly depend on the mitochondrial $\mathrm{Ca}^{2+}$ uptake [1]. Although the mitochondrial $\mathrm{Ca}^{2+}$ uptake in cardiomyocytes constitutes less than $1 \%$ and the mtCU current is surprisingly low as compared to other tissues $[93,94]$, it is definitely a key player coordinating the balance between energy supply and demand (excitation-metabolism coupling) [3]. Precise mechanisms regulating the mitochondrial $\mathrm{Ca}^{2+}$ handling in cardiomyocytes were described during the last decade [13].

After determination of the mtCU molecular identity, its role in the cardiac muscle has been widely investigated by using genetic manipulations. The whole-body MCU KO mice displayed unaffected cardiac function both under basal and stress conditions [58]. On the other hand, mice with a short-term cardiac-specific MCU KO displayed unchanged phenotype under basal conditions but showed an impaired adaptive response to acute stress $[95,96]$.

$\mathrm{Ca}^{2+}$ entry through the L-type $\mathrm{Ca}^{2+}$-channels in cardiomyocytes induces $\mathrm{Ca}^{2+}$ delivery from the sarcoplasmic reticulum (SR) ryanodine receptors (RyR2) leading to formation of $\mathrm{Ca}^{2+}$ microdomains nearby the SR-mitochondria junction and further $\mathrm{Ca}^{2+}$ signal transduction into mitochondria via mtCU [97]. It should be noted, however, that exact composition of $\mathrm{Ca}^{2+}$ microdomains in cardiomyocytes is not yet fully understood. Indeed, $\mathrm{mtCU}$ was initially reported to be homogeneously distributed in the mitochondrial inner membrane, as observed in intact ventricular cardiomyocytes of adult rabbit [98]. A more recent study on submitochondrial membrane fractions obtained from mouse and rat heart mitochondria revealed that $\mathrm{mtCU}$ are concentrated at the SR-mitochondria contact sites at the mitochondrial periphery to promote effective $\mathrm{Ca}^{2+}$ transport [99]. Along the same line, this scientific group later reported spatial segregation of the mitochondrial $\mathrm{Ca}^{2+}$ efflux via NCLX from the mitochondrial $\mathrm{Ca}^{2+}$ uptake via $\mathrm{mtCU}$ [100]. The lack of $\mathrm{Ca}^{2+}$ extrusion at the most $\mathrm{Ca}^{2+}$-exposed area serves for optimization of the $\mathrm{Ca}^{2+}$ signaling efficiency and minimization of the energy costs [100]. The controversy concerning the distribution of $\mathrm{mtCU}$ in the inner mitochondrial membrane may be explained by the difference in experimental approaches as well as by species- or age-specific characteristics of cardiomyocytes. Overall, it is still difficult to draw any definite conclusions, and further investigations are required.

The kinetics of mitochondrial $\mathrm{Ca}^{2+}$ concentration in adult ventricular cardiomyocytes during excitation-contraction coupling is also debatable [1]. Cao et al. discussed two models proposed for the $\mathrm{Ca}^{2+}$ dynamics in cardiac mitochondria [13]. According to the first model, $\mathrm{Ca}^{2+}$ concentration in cardiac mitochondria oscillates in a beat-to-beat manner, whereas the second model assumes gradual mitochondrial $\mathrm{Ca}^{2+}$ uptake. The authors emphasize that the mitochondrial $\mathrm{Ca}^{2+}$ dynamics, which may depend on the animal species and pacing frequency, needs further investigation [13].

\subsection{MtCU in Cardiac Hypertrophy}

Myocardium hypertrophy can be defined as an increase in the myocardial mass. It is well known, that in mammals the majority of cardiomyocytes lose the ability to proliferate shortly after the birth, and the subsequent heart growth proceeds mostly by an increase in the cardiomyocyte cell size. This is true under both normal physiological (growth, pregnancy, chronic exercise training) and pathological (hypertension, sarcomeric gene mutations, etc.) conditions [101]. Physiological cardiac hypertrophy during postnatal development is accompanied by both an increase in cell size and 
pronounced remodeling, including redistribution of mitochondria to the $\mathrm{Ca}^{2+}$ microdomains and SR maturation [102]. However, the data on the role of $\mathrm{mtCU}$ in cardiomyocyte maturation are extremely limited. Zaglia et al., for the first time demonstrated decreased MCU protein levels and the reciprocal miR-1 upregulation in the adult hearts as compared with the neonatal hearts in mice and humans, and concluded that the miR-1/MCU axis takes part in the postnatal cardiomyocyte maturation [72]. Increased cardiac pressure load during exercises or aortic stenosis caused a decrease in miR-1 and, accordingly, increased the MCU content indicating similar initial cardiomyocyte adaptation (Figure 2). However, the signs of local tissue damage and the substantially increased mRNA expression of the pore-inhibiting subunit MCUb were observed only under the pathological overload [72]. The increased MCU content in the ventricular myocardium during the pressure overload-induced hypertrophy is accompanied by autophagy inhibition and histological changes [103]. Therefore, although the pathological cardiac hypertrophy is compensated at the initial step, its further progression leads to decompensation and contributes to the development of severe cardiovascular disorders, such as arrhythmias and heart failure.

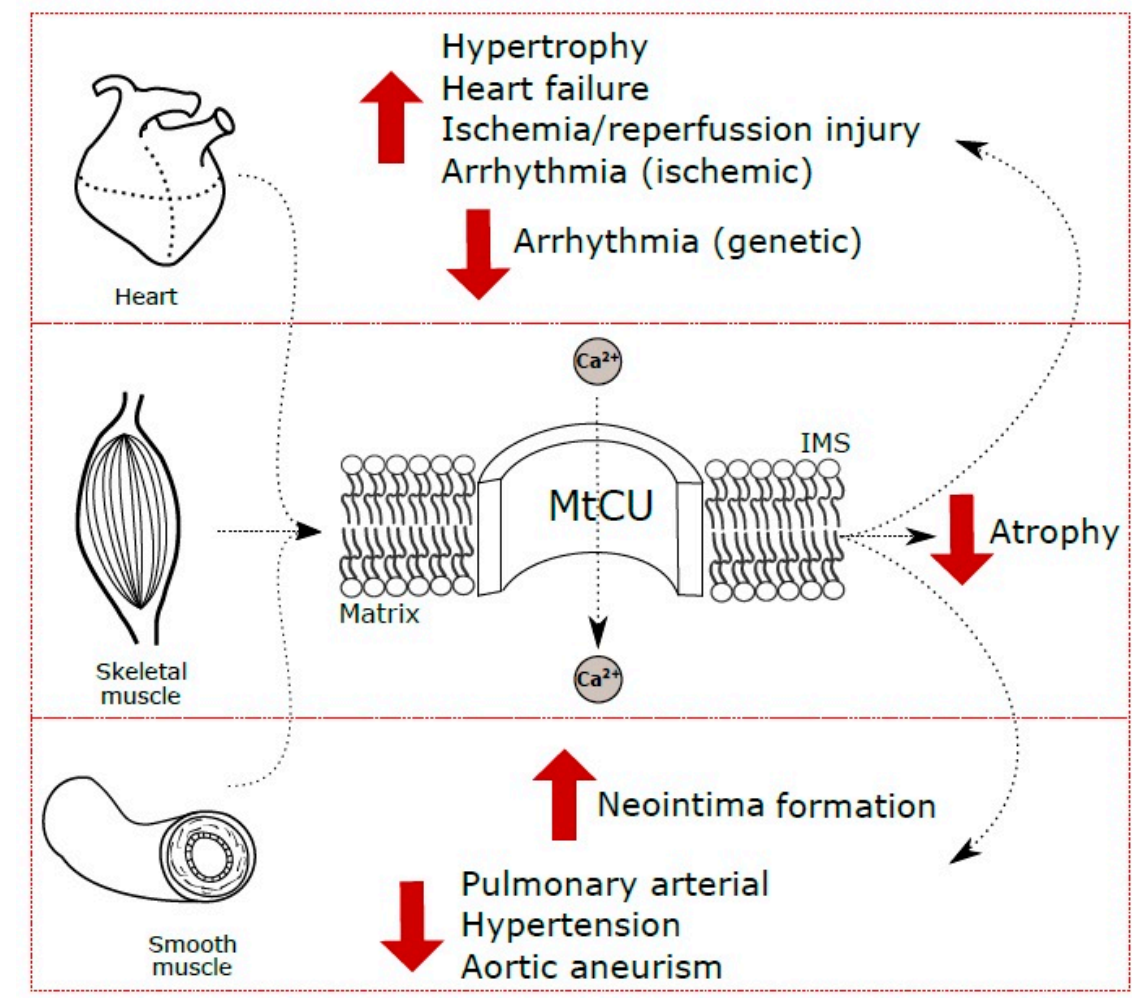

Figure 2. A summarizing scheme on the role of mtCU in pathological conditions of cardiac, skeletal and smooth muscle. Red arrows indicate the hyperfunction (up) or hypofunction (down) of mtCU complex associated with the pathology. IMS—intermembrane space.

As expected, the mtCU inhibition under the overload-induced hypertrophy improved the cardiac function and mitigated the pathological changes [103]. On the other hand, the absence of MCU protein expression did not prevent the development of the overload-induced cardiac hypertrophy in MCU-/mice [58]. This contradiction once again emphasizes the multifactorial etiology of cardiovascular diseases, as well as the necessity for precise regulation of mitochondrial $\mathrm{Ca}^{2+}$ homeostasis, reliably compensated in the case of congenital defects in corresponding genes.

\subsection{MtCU in Arrhythmogenesis}

Arrhythmias represent one of the primary causes of sudden cardiac death and a severe complication after acute ischemia and myocardial infarction [104,105]. 
Several heart diseases, including nonischemic heart failure and myocardial ischemia, are associated with increased arrhythmia risks and triggered activity. The ischemia-induced abnormalities in the ventricular automaticity are supposed to cause arrhythmias and attributed to the disturbed intracellular and, in particular, mitochondrial $\mathrm{Ca}^{2+}$ handling [106]. Mitochondrial $\mathrm{Ca}^{2+}$ uptake via mtCU modulates the spontaneous electrical activity of ventricular-like cardiomyocytes derived from mouse embryonic stem cells, together with RyR2 and IP3Rs at sarcoplasmic reticulum, while the plasmalemmal Ca-L-channels and NCX ensure the cell automaticity [107]. The beating rate of ventricular-like cardiomyocytes [107], as well as ventricular fibrillation after adrenergic stimulation in isolated hearts with pressure overload-induced hypertrophy [108], were substantially reduced after mtCU inhibition with selective inhibitor Ru360. On the other hand, direct stimulation of mtCU with natural plant flavonoid kaempferol exacerbated the mitochondrial $\mathrm{Ca}^{2+}$ accumulation and spontaneous premature ventricular contractions [108]. Consistent data were obtained on MCU knockdown mice and the mouse ventricular cell computer model and simulation [109]. In contrast, anti-arrhythmogenic effect was observed after mtCU activation in catecholaminergic polymorphic ventricular tachycardia (CPVT), a disease associated with mutation in RYR2 and characterized by episodes of life-threatening ventricular tachycardia upon the catecholaminergic stimulation after physical exercise or emotional stress [110]. Indeed, stimulation of mtCU with kaempferol led to enhanced mitochondrial $\mathrm{Ca}^{2+}$-uptake after the release of $\mathrm{Ca}^{2+}$ from SR and eliminated the arrhythmogenic $\mathrm{Ca}^{2+}$ waves induced by catecholaminergic stimulation in the CPVT murine cardiomyocytes [110]. These contradictions may originate from differences in both the experimental approaches and model objects. In particular, the embryonic stem cells-derived ventricular-like cardiomyocytes possess their own spontaneous electrical activity, while the adult ventricular cardiomyocytes do not. At the same time, arrhythmia during the pressure overload-induced hypertrophy is associated with excessive mechanical work of myocardium, while in CPVT it is caused by a genetic defect.

Therefore, although the regulation of mitochondrial $\mathrm{Ca}^{2+}$ handling by $\mathrm{mtCU}$ is likely to provide a versatile mechanism for adjusting the electrical activity of pacemaker cells, the attempts to modulate it with pharmacological agents may lead to adverse consequences and should be studied in more detail.

Disturbances in functioning of the $\mathrm{mtCU}$ regulators are also associated with the development of arrhythmias. For instance, Ucp2-/- mice have more pronounced susceptibility to the $\mathrm{Ca}^{2+}$ overload-induced arrhythmias and increased PRMT1 protein levels, which may be responsible for the decreased mitochondrial $\mathrm{Ca}^{2+}$-uptake in the Ucp2-/- hearts [111]. It is important to note that the UCP polymorphisms in humans are known to be associated with the heart rate variability [112]. Although the protective role of other mtCU regulators, Pyk2 and Akt, to some extent counteracts arrhythmogenesis $[113,114]$, the mechanism has not yet been studied in detail and consideration of Pyk2 and Akt as anti-arrhythmogenic targets may require further investigation.

\subsection{MtCU in Myocardial Ischemia/Reperfusion Injury}

Ischemic heart disease remains a major factor of death and disability worldwide [115], and the mitochondrial $\mathrm{Ca}^{2+}$ mishandling in cardiomyocytes during ischemia/reperfusion injury is well documented [116]. The cardiomyocyte death following ischemic episode is mainly caused by $\mathrm{Ca}^{2+}$ overload-induced ROS generation and MPTP opening.

The role of $\mathrm{mtCU}$ in the cardiomyocyte cell death was assessed on different genetically modified models. In particular, an inducible tissue-specific $\mathrm{Mcu}$ deletion in the adult heart does not compromise the myocardial energy production and contractile function due to a compensatory increase in the fatty acid oxidation both under basal conditions and during the acute adrenergic challenge [117]. Moreover, such a deletion protects cardiomyocytes from mitochondrial $\mathrm{Ca}^{2+}$ overload and acute ischemia-reperfusion injury $[95,96]$. In line with these findings, the siRNA-mediated MCU silencing in vitro efficiently reduced mitochondrial $\mathrm{Ca}^{2+}$ overload, mPTP opening and cardiomyocyte death activation after hypoxia-reoxygenation [118]. On the other hand, myocardium-specific expression of a dominant negative form of MCU protein, induced before the birth, did not protect from the myocardial 
tissue death despite the preserved mitochondrial membrane potential and reduced ROS generation during ischemia/reperfusion [119]. These controversial observations led to a hypothesis that MCU deletions prior to birth result in compensatory changes in mitochondrial cell death pathways, and the protective effect of MCU depletion is dependent on the time of induction but not tissue specificity [120]. Indeed, a higher mPTP sensitivity to $\mathrm{Ca}^{2+}$ associated with the increased phosphorylation of cyclophilin $\mathrm{D}$ at Ser42 were observed in the hearts of conventional (whole-body) MCU KO mice, while the receptor interacting protein (RIP3) kinase-activated cell death pathway had no significant contribution to ischemia/reperfusion injury [120].

Conductance of $\mathrm{mtCU}$ channel is tightly regulated by auxiliary subunits; therefore, the resistance of cardiomyocytes to ischemia may be affected by alterations in either subunits expression or their association with MCU to form the whole mtCU complex. Indeed, the MICU1 protein content in mitochondria was significantly reduced following ischemia/reperfusion, despite the unchanged total MICU1 content, due to the inhibited expression of translocase of outer membrane 70 (Tom70) leading to the impaired MICU1 import into mitochondria [121]. Furthermore, targeting of myocardial MICU1 with siRNA significantly exacerbated the consequences of ischemic episode by increasing the infarction area, depressing cardiac function and increasing the myocardial apoptosis; the effects resulted from mitochondrial $\mathrm{Ca}^{2+}$ overload with consequent ATP depletion and morphological defects [121].

\subsection{MtCU in Heart Failure}

Heart failure is reported to be the prevalent reason for hospital admissions in some developed countries, and the imbalanced $\mathrm{Ca}^{2+}$-dependent regulation of oxidative metabolism is widely accepted as a key factor in its pathogenesis [122,123]. In particular, sustainably elevated cytoplasmic $\mathrm{Ca}^{2+}$ concentrations resulting from decreased SERCA expression or activity, along with $\mathrm{Ca}^{2+}$ leakage via RyR2, may lead to mitochondrial $\mathrm{Ca}^{2+}$ overload [1]. This, in turn, results in the elevated ROS levels and reduced ATP production, and eventually leads to maladaptive myocardium remodeling and contractile impairment [13]. Initial attempts to assess the physiological role of mtCU by using a conventional (whole-body) KO model surprisingly revealed that the absence of MCU expression has no influence on the cardiac morphology and function under basal conditions and is certainly insufficient to prevent the pressure overload-induced heart failure, despite the markedly impaired mitochondrial calcium handling [58]. At the same time, the isolated hearts of mice with myocardium-delimited transgenic expression of a dominant negative form of MCU protein showed the increased oxygen consumption indicative of lower efficiency, despite the unaltered myocardium morphology and mitochondrial structure [119]. The lack of $\mathrm{mtCU}$-mediated mitochondrial $\mathrm{Ca}^{2+}$ entry in cardiomyocytes could be compensated by changes in cytoplasmic $\mathrm{Ca}^{2+}$ homeostasis manifested as unchanged oxygen consumption by the isolated cardiac mitochondria [119]. Interestingly, the opposite situation is observed for the inducible cardiac-specific MCU deficiency: this model shows an increased cardiac output associated with the enhanced fatty acid oxidation, and the unchanged levels of glucose oxidation [117].

Heart failure progression is accompanied by an increase in the myocardial MCU protein content reaching the highest point during the compensatory hypertrophic phase. The MCU upregulation is accompanied by autophagy blockade, as indicated by an increase in the p62 (SQSTM1) protein content resulting from its reduced degradation [103]. Interestingly, pharmacological inhibition of mtCU restores the levels of autophagy and mitophagy, partially prevents both the cardiomyocytes hypertrophy and myocardial fibrosis, and alleviates the concomitant ventricular asynchrony [103]. On the other hand, correction of cardiac dysfunction by cardiac resynchronization therapy provides mitochondrial fission and autophagosome/mitophagosome formation underlying the alleviated cell enlargement and myocardial fibrosis [124]. This therapeutic approach leads to a significant reduction in MCU and p62 content accompanied by DRP1 upregulation [124], which brings up an important question of $\mathrm{mtCU}$ participation in the mitochondria quality control. Cho et al. have recently reported that mtCU mediates the DRP1-dependent $\mathrm{Zn}^{2+}$ influx into the mitochondrial intermembrane space during fission [125]. Although the compromised mitochondria quality control in heart failure has been 
documented [123], further studies are needed to clarify whether this mechanism is crucial for the heart failure progression.

In contrast to $\mathrm{Mcu}-/-$ mice, which show a mild phenotype, the Micu2-/- mice have increased left atrium diameter resulting from the retarded cardiomyocyte relaxation and consequent diastolic dysfunction [51]. These dysfunctional changes develop despite the compensatory enhanced SERCA expression and normal myocardial structure [51], emphasizing the important role of mtCU regulatory subunits and upstream regulatory molecules in the mitochondrial $\mathrm{Ca}^{2+}$ handling under pathological conditions. For instance, miR-1 is being extensively studied as a potential therapeutic target, given its contribution to cardiac hypertrophy [72] and remodeling [126] and its association with heart failure [127], whereas mtCU has been identified as a downstream target of miR-1 in the hypertrophic changes realization [72]. Nevertheless, prognostic value of miR-1/mtCU axis in the heart failure progression has not been assessed thoroughly. As far as the CaMKII/mtCU axis role in heart failure is concerned, although CaMKII has been shown to cause heart failure through the mtCU activation and mPTP opening leading to cardiomyocyte death [30], contradictory data about the direct regulation of mtCU by CaMKII $[30,31,77]$ do not allow us to make unambiguous conclusions at this point until further investigation.

The imbalance in mitochondrial $\mathrm{Ca}^{2+}$ may also be associated with the disturbed $\mathrm{Ca}^{2+}$ efflux from mitochondria. The mitochondrial $\mathrm{Na}^{+} / \mathrm{Ca}^{2+}$ exchanger is essential for $\mathrm{Ca}^{2+}$ homeostasis, as its inducible deletion in mice leads to sudden death caused by myocardial dysfunction and heart failure [128]. The correct balance of non-mtCU molecules is therefore essential for the prevention of heart failure.

\section{The Role of MtCU in Skeletal Muscle}

\subsection{General Role of MtCU in Skeletal Muscle}

The major role of skeletal muscle is the conversion of chemical energy into mechanical movements necessary for the realization of many vital functions [129]; an increase of $\mathrm{Ca}^{2+}$ concentration in the sarcoplasm is essential for skeletal muscle contraction [130].

Since mitochondrial $\mathrm{Ca}^{2+}$ handling is crucial for the adaptation of energy production to the immediate energy demands of the muscle, and also provides a link between excitation and transcription, the mtCU function in skeletal muscle is widely investigated [130]. Large body of valuable data on the role of $\mathrm{mtCU}$ in skeletal muscle was obtained on models with mtCU deficiency (as in the case with myocardial tissue). The role of MCU as a trophic factor was initially revealed in adult mice with muscle-targeted MCU overexpression or silencing as a cause of muscle hypertrophy or atrophy, respectively [131]; these findings were consistent with the smaller size of muscle fibers in muscle-targeted MCU KO mice [131,132] and the decreased body weight of conventional (whole-body) MCU KO mice [133]. However, more recent study did not show direct influence of the muscle-specific Mcu depletion on body weight, muscle weightm and fiber size regardless of the age of gene loss induction [134]. Some discrepancies between the models are also observed for the basal mitochondrial $\mathrm{Ca}^{2+}$ level. Whereas the basal mitochondrial $\mathrm{Ca}^{2+}$ concentrations were substantially reduced in the whole-body KO and adult muscle-specific Mcu depletion models [131,133], in a skeletal muscle-specific loss-of-function model they were unaffected [134]. Nevertheless, the relevance of all models was confirmed by observations of the blunted mitochondrial $\mathrm{Ca}^{2+}$ uptake in skeletal muscle in response to different stimuli [131-134]. A metabolic shift toward fatty acid oxidation in skeletal muscle of MCU-deficient mice was reported [132,134]. Consistently, impaired glucose oxidation in these animals was observed due to a decreased activity of pyruvate dehydrogenase regulating the flow of primary glucose metabolites to mitochondrial oxidative phosphorylation [131,133]. Interestingly, the in vivo effects of $\mathrm{Mcu}$ depletion may also depend on the experimental approach. For instance, impaired performance of the animals in the intense muscle exercise tests was demonstrated for the whole-body [133] and muscle-specific Mcu deletion [132]. However, other authors observed similar 
impairments only when using the exercise protocol without a warm-up period [134]; after a long adaptation to running, the performance of KO mice was similar to the control group [134].

Mcu deletion in skeletal muscle tissue not only affects muscle metabolism, but also triggers systemic metabolic adaptations [132]. Indeed, gluconeogenesis enzymes were upregulated in the liver of mice with skeletal muscle-specific $\mathrm{Mcu}$ deletions. At the same time, reduced blood levels of glucose were accompanied by increased glucose uptake in muscles. Taken together, these observations indicate systemic metabolic adaptations allowing the liver to counteract excessive muscle glucose uptake and maintain euglycemia [132].

\subsection{Specific Features of MtCU in Skeletal Muscle}

Skeletal muscle tissue is one of the top energy consumers in the body and therefore has special needs of rapid and tightly controlled energy production. Since mitochondrial $\mathrm{Ca}^{2+}$ directs the conversion of nutrient energy into ATP by activating the $\mathrm{Ca}^{2+}$-dependent dehydrogenases of the tricarboxylic acid cycle, regulation of mitochondrial $\mathrm{Ca}^{2+}$ uptake is a crucial point for the proper muscular contractions [130]. An alternative splice variant of MICU1, called MICU1.1, forms a dimer with MICU2 (as MICU1 does) activating mtCU and promoting $\mathrm{Ca}^{2+}$ uptake at much lower cytosolic $\mathrm{Ca}^{2+}$ concentrations than conventional MICU1-MICU2 does. At low $\mathrm{Ca}^{2+}$ concentrations, MICU1.1 is also capable of gatekeeping. The effect is explained by the increased $\mathrm{Ca}^{2+}$ affinity of MICU1.1, which is an order of magnitude higher than that of MICU1, as estimated by isothermal titration calorimetry [47]. The exact mechanism of boosting of the EF-hand $\mathrm{Ca}^{2+}$ binding affinity by MICU1.1 extra exon remains obscure. Therefore, in this case alternative splicing works as a means of adaptation of mitochondrial $\mathrm{Ca}^{2+}$ uptake to energetic demands of a particular tissue.

\subsection{MtCU in Skeletal Muscle Dysfunction, Injury and Ageing}

MtCU dysfunction associated with MICU1 intronic insertions causing frameshifts and leading to significant downregulation of MICU1 mRNA levels has been identified. Clinical phenotype of these patients comprising proximal muscle weakness, learning difficulties and progressive extrapyramidal movement disorder [135]. In accordance with the mtCU gatekeeper role of MICU1 [41], cell cultures derived from these patients showed the enhanced $\mathrm{Ca}^{2+}$ uptake at low cytosolic $\mathrm{Ca}^{2+}$ concentrations and the damping of cytosolic $\mathrm{Ca}^{2+}$ signals due to increased mitochondrial $\mathrm{Ca}^{2+}$ buffering [135]. Moreover, increased rates of mitochondrial fission (mediated by the elevated activity of DRP1 [136] in the MICU1-deficient cells with chronically activated mtCU [135]) result in highly fragmented mitochondrial networks. This finding additionally illustrates the regulatory function of the uniporter in the mitochondrial quality control system. Further analysis of the identified mutant phenotypes revealed a compensatory increase in $\mathrm{Ca}^{2+}$ efflux via NLCX, counteracting the increased mitochondrial $\mathrm{Ca}^{2+}$ uptake [136]. As a result, the sodium-proton exchanger (NCX) is also activated, which attenuates the proton-motive force required for ATP synthesis. Eventually, these mechanisms cause muscle weakness concomitant with the mutations [136]. In line with this data, the loss of MICU1 protein expression due to deletion of exon 1 of MICU1 causes fatigue, lethargy, and weakness [137]. Mitochondrial $\mathrm{Ca}^{2+}$ uptake is also substantially impaired in the cells derived from these patients [137]. Surprisingly, the loss of MICU1 does not affect oxygen consumption or membrane potential [135,137]; this finding is consistent with the data for a MICU1 in vivo silencing murine model [53]. Another recent report focuses on novel nonsense MICU1 mutations [138], previously documented as minor alleles [139]. The authors identified 13 patients from Middle East who manifested characteristic symptoms of MICU1 deficiency, including muscle weakness and easy fatigability [138]. Overall, different MICU1 mutations lead to similar effects and severe phenotypes resembling mitochondrial diseases, which should be accounted for in diagnostics.

The beneficial role of mtCU-dependent mitochondrial $\mathrm{Ca}^{2+}$ uptake in skeletal muscles following muscle injury has also been demonstrated [140]. Specifically, $\mathrm{Ca}^{2+}$ activates mitochondrial ROS production which, in turn, facilitates the myocyte membrane repair by local activation of RhoA 
and triggering F-actin accumulation at the site of injury. Both mtCU inhibition and ROS quenching compromise the plasma membrane repair. Interestingly, this mechanism is common for myoblasts, mature skeletal myofibers, and nonmuscle cells [140]. These findings emphasize the role of $\mathrm{mtCU}$ in skeletal muscle repair and the positive role of ROS as valuable signaling molecules.

Since $\mathrm{mtCU}$ has been characterized as a trophic factor in skeletal muscle, therapeutic approaches leading to increased $\mathrm{mtCU}$ expression or activity should be considered for the treatment of various atrophic muscle diseases, for example, age-related sarcopenia. Leg press exercise training and neuromuscular electrical stimulation of the anterior thigh quadriceps muscles beneficially affected the structure and function of the muscle tissue in 70-year-old sedentary volunteers [141]. In detail, the improvement in muscle strength and the recovery of the myofiber structure was accompanied by an increase in MCU protein expression without changes in the MCU mRNA levels (suggesting post-transcriptional regulation). Additionally, the expression of hypertrophy-associated genes (e.g., IGF1) was induced by the training, concomitantly with the inhibitory effect on atrophy-associated genes (e.g., MuRF1). It should be noted that neuromuscular electrical stimulation has a more profound effect than conventional physical exercise training, and may be considered as an alternative to the traditional rehabilitation therapy [141]. On the other hand, excessive expression of MCU in mice with impaired mitochondrial quality control contributes to mitochondrial $\mathrm{Ca}^{2+}$ overload, myocyte cell death, and skeletal muscle atrophy [74]. This effect is mediated by DRP1-miR1-MCU axis: Drp1 inhibition downregulates miR1, leading to increased MCU protein levels. Simultaneously, MCU inhibition normalizes $\mathrm{Ca}^{2+}$ handling and ameliorates myofiber survival [74]. Altogether, these findings indicate the importance of proper $\mathrm{Ca}^{2+}$ balance, achieved by proper regulation of mtCU activity, for normal skeletal muscle functioning and prevention of muscular atrophy.

MtCU-associated function disturbances may be associated not only with structural and functional impairments of the complex itself, but also with its abnormal regulation. In particular, null mutations in the m-AAA protease SPG7 in Drosophila lead to multiple degenerative changes, including skeletal muscle degeneration accompanied by accumulation of morphologically and functionally abnormal mitochondria [92]. Although this model recapitulates some features of the hereditary spastic paraplegia and could be relevant for understanding its molecular pathology, applicability of this model for development of new therapies for paraplegia requires proper validation.

\section{MtCU in Smooth Muscle Pathologies}

The role of mtCU in smooth muscle cells has been mainly investigated in terms of vascular smooth muscle physiology and dysfunction, since VSMCs are crucial players in the pathophysiology of hypertension, which contributes to the development of heart failure, myocardial infarction, stroke and other severe disorders [142]. For instance, studies on the influence of mtCU blockers on cerebral blood flow preceded the discovery of mtCU molecular components [143]. Nevertheless, the number of studies on the role of mtCU in smooth muscle is limited.

VSMC plasticity (the capability of the contractile-to-synthetic shift in phenotype) is pivotal for the vascular wall repair during the phase of cell migration and proliferation following injury. By contrast, if the vascular function is impaired chronically, as occurs in atherosclerosis and neointima formation, VSMC plasticity contributes to the pathology progression [144]. Mitochondrial $\mathrm{Ca}^{2+}$ uptake via mtCU is essential for mitochondrial mobility and the isolated aortic VSMCs migration during neointima formation, with CaMKII as an upstream regulator of this process [79]. The CaMKII or mtCU inhibition predictably abrogated VSMCs migration and mitochondrial translocation to the leading edge [79] suggesting this pathway as a novel therapeutic option to mitigate the neointimal hyperplasia.

The excessive artery smooth muscle cells proliferation, migration, and apoptosis resistance are also typical of pulmonary arterial hypertension [70]. In contrast to aortic VSMCs, the pulmonary artery smooth muscle cells (PASMCs) from the patients with pulmonary arterial hypertension showed decreased content of mitochondrial $\mathrm{Ca}^{2+}$ in combination with increased content of cytosolic $\mathrm{Ca}^{2+}$ which contribute to PASMC proliferation and migration. PASMC $\mathrm{Ca}^{2+}$ disturbances are attributed to $\mathrm{MCU}$ 
downregulation and coordinated reciprocal upregulation of MICU1 resulting in the impaired mtCU function. Along the same line, inhibition of $\mathrm{mtCU}$ in normal PASMCs reproduced the pulmonary artery hypertension phenotype [69]. Disturbed mitochondrial $\mathrm{Ca}^{2+}$ handling was also identified for maternally-inherited hypertension associated with a mutation in mitochondrial DNA [145]. In particular, Chen et al. revealed the lowest mitochondrial $\mathrm{Ca}^{2+}$ in combination with the highest cytoplasmic $\mathrm{Ca}^{2+}$ in lymphoblastoid cell lines derived from hypertensive patients carrying the mitochondrial DNA mutation in comparison with both hypertensive patients without the mutation and normotensive carriers of the mutation. The decreased MCU expression was characteristic of the cells from hypertensive patients both with mutation and without it [145]. Unfortunately, the paper provides neither mechanistic insights nor matching experiments with VSMCs.

The hypertension, induced by chronic infusion of angiotensin II in the Micu2-depleted mice, led to a progressive increase in the aortic diameter and eventually to aneurysms in some animals, although the initial aortic diameter in Micu2-/- mice was only slightly larger than in normal animals. Interestingly, this effect was specific for angiotensin II and was not reproduced by the treatment of Micu2-/- animals with norepinephrine. Transcriptional profiling of aortic VSMCs revealed dysregulation including proinflammatory signature, increased extracellular matrix remodeling, and cell proliferation [51]. Therefore, genetic defects in the mtCU subunit-encoding genes can exacerbate the adverse effects of cardiovascular pathologies. Although the issue is beyond the scope of this review, endothelial dysfunction contributing to the disease progression should be also taken into consideration when discussing hypertension.

The data concerning mtCU function in the smooth muscle from non-vascular locations are extremely scarce and indirect, although the mitochondrial $\mathrm{Ca}^{2+}$ mishandling in smooth muscle tissue is typical for a number of diseases. For instance, hyper-responsiveness of the airway smooth muscle in asthma results from the elevated cytoplasmic $\mathrm{Ca}^{2+}$ very probably associated with dysregulated mitochondrial $\mathrm{Ca}^{2+}$ buffering [146]. Inhibitory analysis indicated the mtCU-mediated mitochondrial $\mathrm{Ca}^{2+}$ buffering of cytosolic $\mathrm{Ca}^{2+}$ elevations in the histamine-stimulated airway smooth muscle cells [147], suggesting the involvement of mitochondrial $\mathrm{Ca}^{2+}$ buffering in shaping of cytoplasmic $\mathrm{Ca}^{2+}$ responses. Interestingly, the observed differential responses of perinuclear and peripheral mitochondrial populations indicate the tight control of local $\mathrm{Ca}^{2+}$ concentrations and adaptation to specific energy demands in different cellular compartments [147]. Expression of mtCU components in myometrium along the course of human pregnancy has been recently analyzed [148]. The opposite dynamics between mRNA and protein expression was revealed for MCU and MCUb subunits: An abrupt transcriptional decline in the whole-term pregnancy was accompanied by increase in the corresponding protein levels. This pattern may be associated with the myometrial hypertrophy during gestation or with preparation to coordinated contractions at childbirth [148]. Overall, the role of mtCU in smooth muscle physiology and pathology remains largely understudied and further findings in this field are expected.

\section{Future Directions and Conclusions}

$\mathrm{MtCU}$ is the major route for the $\mathrm{Ca}^{2+}$ influx to mitochondria, and its contribution to pathophysiology has been demonstrated for a number of cardiovascular and skeletal muscle diseases. Therefore, modulation of $\mathrm{mtCU}$ expression and activity represents a promising molecular target. Ruthenium red and its derivatives are usually used for inhibition of $\mathrm{mtCU}$ in the experiments. However, ruthenium red, along with the inhibition of $\mathrm{mtCU}$, has nonspecific activity against some other ion channels [149], which prevents its use as a therapeutic agent. Use of the more selective ruthenium red derivative, Ru360, is also limited as it is plasma membrane-impermeable, and its synthesis is challenging [150]. Two cell-permeable and highly selective small-molecule mtCU inhibitors were recently developed: DS16570511 [151] and ruthenium complex Ru265 [150]. DS16570511 effectively blocks $\mathrm{Ca}^{2+}$ overload and increases cardiac contractility without affecting heart rate [151]. Ru265 is minimally toxic and prevents hypoxia/reoxygenation injury in cell model [150]. Anti-cancer drug mitoxantrone effectively 
inhibits mtCU activity, but its therapeutic use is limited by its cytotoxicity [152]. MtCU activators should also be considered as therapeutic agents for $\mathrm{mtCU}$-associated pathologies. For instance, kaempferol, widely studied for its anti-cancer [153] and cardioprotective [154] properties, could be a promising agent in the prevention of $\mathrm{Ca}^{2+}$-triggered arrhythmias [110]. Even though these compounds have a prominent effect on $\mathrm{mtCU}$-associated pathologies and may be promising drugs, they require more detailed validation in cardiovascular and muscle disease animal models before being introduced into clinical practice.

The mitochondrial $\mathrm{Ca}^{2+}$ uptake via $\mathrm{mtCU}$ is a crucial process for the life of a cell. The controllable influx of $\mathrm{Ca}^{2+}$ ensures proper energy production and its adaptation to the immediate needs in the tissues with high energy demands, such as cardiac and skeletal muscle tissues. In addition to the energy production, mitochondrial $\mathrm{Ca}^{2+}$ regulates a variety of myocyte functions including trophism, cell division, and cell death. MtCU expression and activity are tightly regulated by the number of intracellular signaling pathways, with some peculiarities in different types of muscle tissues. Disruptions in mitochondrial $\mathrm{Ca}^{2+}$ handling significantly increase the risks of cell and tissue dysfunction and ultimately result in the development of different pathologies. Cardiovascular diseases, currently known as one of the leading causes of death, and some skeletal muscle pathologies are shown to be associated with $\mathrm{mtCU}$ dysfunction. Therefore, a better understanding of fundamental mechanisms of mtCU function and dysfunction in muscle tissues may be useful for the future development of new modulators of mtCU activity and perspective therapy approaches.

Author Contributions: Writing—original draft preparation, N.V.T., P.A.V., Y.A.L.; writing—review and editing, N.V.T., P.A.V., Y.A.L.; supervision, N.V.T., A.V.E.; project administration, N.V.T., A.V.E.

Funding: This research was funded by President Grant for Government Support of Young Russian Scientists No. 075-15-2019-1120. Work of P.V. was supported by the President's Scholarship (SP-4132.2018.4). The publication has been prepared with the support of the "RUDN University Program 5-100".

Conflicts of Interest: The authors declare no conflict of interest.

$\begin{array}{ll}\text { Abbreviations } \\ \text { CaMKII } & \text { calmodulin-dependent protein kinase II } \\ \text { CCD } & \text { coiled-coil domain } \\ \text { CPVT } & \text { catecholaminergic polymorphic ventricular tachycardia } \\ \text { CREB } & \text { cyclic AMP response element binding protein } \\ \text { cryo-EM } & \text { cryo-electron microscopy } \\ \text { DRP1 } & \text { dynamin-related protein 1 } \\ \text { EMRE } & \text { essential MCU regulator } \\ \text { KO } & \text { knockout } \\ \text { MCU } & \text { mitochondrial calcium uniporter pore-forming subunit } \\ \text { MICU1 } & \text { mitochondrial calcium uptake 1 } \\ \text { MICU2 } & \text { mitochondrial calcium uptake 2 } \\ \text { miR } & \text { microRNA } \\ \text { mtCU } & \text { mitochondrial calcium uniporter complex } \\ \text { NCX } & \text { Na+/Ca }{ }^{2+} \text { exchanger } \\ \text { NMR } & \text { nuclear magnetic resonance } \\ \text { NTD } & \text { N-terminal domain } \\ \text { PASMC } & \text { pulmonary artery smooth muscle cells } \\ \text { PRMT1 } & \text { protein arginine methyl transferase 1 } \\ \text { RIPK1 } & \text { receptor-interacting protein kinase 1 } \\ \text { ROS } & \text { reactive oxygen species } \\ \text { RyR2 } & \text { ryanodine receptor 2 } \\ \text { SERCA } & \text { sarcoplasmic/endoplasmic reticulum Ca }{ }^{2+} \text { ATPase } \\ \text { SR } & \text { sarcoplasmic reticulum } \\ \text { TMD } & \text { transmembrane domain } \\ \text { VSMCs } & \text { vascular smooth muscle cells }\end{array}$




\section{References}

1. Giorgi, C.; Marchi, S.; Pinton, P. The machineries, regulation and cellular functions of mitochondrial calcium. Nat. Rev. Mol. Cell Biol. 2018, 19, 713-730. [CrossRef] [PubMed]

2. Belosludtsev, K.N.; Dubinin, M.V.; Belosludtseva, N.V.; Mironova, G.D. Mitochondrial Ca ${ }^{2+}$ Transport: Mechanisms, Molecular Structures, and Role in Cells. Biochemistry 2019, 84, 593-607. [CrossRef] [PubMed]

3. Kwong, J.Q. The mitochondrial calcium uniporter in the heart: Energetics and beyond. J. Physiol. 2017, 595, 3743-3751. [CrossRef] [PubMed]

4. Rossi, A.; Pizzo, P.; Filadi, R. Calcium, mitochondria and cell metabolism: A functional triangle in bioenergetics. Biochim. Biophys. Acta Mol. Cell Res. 2019, 1866, 1068-1078. [CrossRef] [PubMed]

5. Eshima, H.; Poole, D.C.; Kano, Y. Mitochondrial calcium regulation during and following contractions in skeletal muscle. J. Phys. Fit. Sports Med. 2018, 7, 205-211. [CrossRef]

6. Zheng, X.; Chen, M.; Meng, X.; Chu, X.; Cai, C.; Zou, F. Phosphorylation of dynamin-related protein 1 at Ser616 regulates mitochondrial fission and is involved in mitochondrial calcium uniporter-mediated neutrophil polarization and chemotaxis. Mol. Immunol. 2017, 87, 23-32. [CrossRef] [PubMed]

7. Paupe, V.; Prudent, J. New insights into the role of mitochondrial calcium homeostasis in cell migration. Biochem. Biophys. Res. Commun. 2018, 500, 75-86. [CrossRef] [PubMed]

8. Bertero, E.; Maack, C. Calcium Signaling and Reactive Oxygen Species in Mitochondria. Circ. Res. 2018, 122, 1460-1478. [CrossRef] [PubMed]

9. Koval, O.M.; Nguyen, E.K.; Santhana, V.; Fidler, T.P.; Sebag, S.C.; Rasmussen, T.P.; Mittauer, D.J.; Strack, S.; Goswami, P.C.; Abel, E.D.; et al. Loss of MCU prevents mitochondrial fusion in G1-S phase and blocks cell cycle progression and proliferation. Sci. Signal. 2019, 12, eaav1439. [CrossRef]

10. Penna, E.; Espino, J.; De Stefani, D.; Rizzuto, R. The MCU complex in cell death. Cell Calcium 2018, 69, 73-80. [CrossRef]

11. Giorgi, C.; Danese, A.; Missiroli, S.; Patergnani, S.; Pinton, P. Calcium Dynamics as a Machine for Decoding Signals. Trends Cell Biol. 2018, 28, 258-273. [CrossRef] [PubMed]

12. Cui, C.; Yang, J.; Fu, L.; Wang, M.; Wang, X. Progress in understanding mitochondrial calcium uniporter complex-mediated calcium signalling: A potential target for cancer treatment. Br. J. Pharmacol. 2019, 176, 1190-1205. [CrossRef] [PubMed]

13. Cao, J.L.; Adaniya, S.M.; Cypress, M.W.; Suzuki, Y.; Kusakari, Y.; Jhun, B.S.; O-Uchi, J. Role of mitochondrial $\mathrm{Ca}^{2+}$ homeostasis in cardiac muscles. Arch. Biochem. Biophys. 2019, 663, 276-287. [CrossRef] [PubMed]

14. Patron, M.; Sprenger, H.G.; Langer, T. m-AAA proteases, mitochondrial calcium homeostasis and neurodegeneration. Cell Res. 2018, 28, 296-306. [CrossRef] [PubMed]

15. Shoshan-Barmatz, V.; De, S. Mitochondrial VDAC, the $\mathrm{Na}+/ \mathrm{Ca}^{2+}$ Exchanger, and the $\mathrm{Ca}^{2+}$ Uniporter in $\mathrm{Ca}^{2+}$ Dynamics and Signaling. In Advances in Experimental Medicine and Biology; Springer: Cham, Switzerland, 2017; Volume 981, pp. 323-347.

16. Pathak, T.; Trebak, M. Mitochondrial $\mathrm{Ca}^{2+}$ signaling. Pharmacol. Ther. 2018, 192, 112-123. [CrossRef]

17. Oxenoid, K.; Dong, Y.; Cao, C.; Cui, T.; Sancak, Y.; Markhard, A.L.; Grabarek, Z.; Kong, L.; Liu, Z.; Ouyang, B.; et al. Architecture of the mitochondrial calcium uniporter. Nature 2016, 533, 269-273. [CrossRef] [PubMed]

18. Wang, Y.; Nguyen, N.X.; She, J.; Zeng, W.; Yang, Y.; Bai, X.; Jiang, Y. Structural Mechanism of EMRE-Dependent Gating of the Human Mitochondrial Calcium Uniporter. Cell 2019, 177, 1252-1261. [CrossRef]

19. Yoo, J.; Wu, M.; Yin, Y.; Herzik, M.A.; Lander, G.C.; Lee, S.Y. Cryo-EM structure of a mitochondrial calcium uniporter. Science 2018, 361, 506-511. [CrossRef] [PubMed]

20. Baradaran, R.; Wang, C.; Siliciano, A.F.; Long, S.B. Cryo-EM structures of fungal and metazoan mitochondrial calcium uniporters. Nature 2018, 559, 580-584. [CrossRef] [PubMed]

21. Fan, C.; Fan, M.; Orlando, B.J.; Fastman, N.M.; Zhang, J.; Xu, Y.; Chambers, M.G.; Xu, X.; Perry, K.; Liao, M.; et al. X-ray and cryo-EM structures of the mitochondrial calcium uniporter. Nature 2018, 559, 575-579. [CrossRef]

22. Baughman, J.M.; Perocchi, F.; Girgis, H.S.; Plovanich, M.; Belcher-Timme, C.A.; Sancak, Y.; Bao, X.R.; Strittmatter, L.; Goldberger, O.; Bogorad, R.L.; et al. Integrative genomics identifies MCU as an essential component of the mitochondrial calcium uniporter. Nature 2011, 476, 341-345. [CrossRef] [PubMed] 
23. De Stefani, D.; Raffaello, A.; Teardo, E.; Szabò, I.; Rizzuto, R. A forty-kilodalton protein of the inner membrane is the mitochondrial calcium uniporter. Nature 2011, 476, 336-340. [CrossRef] [PubMed]

24. Phillips, C.B.; Tsai, C.W.; Tsai, M.F. The conserved aspartate ring of MCU mediates MICU1 binding and regulation in the mitochondrial calcium uniporter complex. Elife 2019, 8, e41112. [CrossRef] [PubMed]

25. Cao, C.; Wang, S.; Cui, T.; Su, X.C.; Chou, J.J. Ion and inhibitor binding of the double-ring ion selectivity filter of the mitochondrial calcium uniporter. Proc. Natl. Acad. Sci. USA 2017, 114, E2846-E2851. [CrossRef] [PubMed]

26. Kirichok, Y.; Krapivinsky, G.; Clapham, D.E. The mitochondrial calcium uniporter is a highly selective ion channel. Nature 2004, 427, 360-364. [CrossRef] [PubMed]

27. Garg, V.; Kirichok, Y.Y. Patch-Clamp Analysis of the Mitochondrial Calcium Uniporter. In Calcium Signalling; Humana: New York, NY, USA, 2019; Volume 1925, pp. 75-86.

28. Patron, M.; Checchetto, V.; Raffaello, A.; Teardo, E.; Vecellio Reane, D.; Mantoan, M.; Granatiero, V.; Szabò, I.; De Stefani, D.; Rizzuto, R. MICU1 and MICU2 finely tune the mitochondrial $\mathrm{Ca}^{2+}$ uniporter by exerting opposite effects on MCU activity. Mol. Cell 2014, 53, 726-737. [CrossRef] [PubMed]

29. Wu, G.; Li, S.; Zong, G.; Liu, X.; Fei, S.; Shen, L.; Guan, X.; Yang, X.; Shen, Y. Single channel recording of a mitochondrial calcium uniporter. Biochem. Biophys. Res. Commun. 2018, 496, 127-132. [CrossRef] [PubMed]

30. Joiner, M.A.; Koval, O.M.; Li, J.; He, B.J.; Allamargot, C.; Gao, Z.; Luczak, E.D.; Hall, D.D.; Fink, B.D.; Chen, B.; et al. CaMKII determines mitochondrial stress responses in heart. Nature 2012, 491, $269-273$. [CrossRef]

31. Fieni, F.; Johnson, D.E.; Hudmon, A.; Kirichok, Y. Mitochondrial $\mathrm{Ca}^{2+}$ uniporter and CaMKII in heart. Nature 2014, 513, E1-E2. [CrossRef] [PubMed]

32. Tsai, C.W.; Tsai, M.F. Electrical recordings of the mitochondrial calcium uniporter in Xenopus oocytes. J. Gen. Physiol. 2018, 150, 1035. [PubMed]

33. Wacquier, B.; Romero Campos, H.E.; González-Vélez, V.; Combettes, L.; Dupont, G. Mitochondrial Ca ${ }^{2+}$ dynamics in cells and suspensions. FEBS J. 2017, 284, 4128-4142. [CrossRef] [PubMed]

34. Lee, S.K.; Shanmughapriya, S.; Mok, M.C.Y.; Dong, Z.; Tomar, D.; Carvalho, E.; Rajan, S.; Junop, M.S.; Madesh, M.; Stathopulos, P.B. Structural Insights into Mitochondrial Calcium Uniporter Regulation by Divalent Cations. Cell Chem. Biol. 2016, 23, 1157-1169. [CrossRef] [PubMed]

35. Dong, Z.; Shanmughapriya, S.; Tomar, D.; Siddiqui, N.; Lynch, S.; Nemani, N.; Breves, S.L.; Zhang, X.; Tripathi, A.; Palaniappan, P.; et al. Mitochondrial Ca ${ }^{2+}$ Uniporter Is a Mitochondrial Luminal Redox Sensor that Augments MCU Channel Activity. Mol. Cell 2017, 65, 1014-1028. [CrossRef] [PubMed]

36. Niescier, R.F.; Hong, K.; Park, D.; Min, K.T. MCU Interacts with Miro1 to Modulate Mitochondrial Functions in Neurons. J. Neurosci. 2018, 38, 4666-4677. [CrossRef] [PubMed]

37. Paillard, M.; Csordás, G.; Huang, K.T.; Várnai, P.; Joseph, S.K.; Hajnóczky, G. MICU1 Interacts with the D-Ring of the MCU Pore to Control Its $\mathrm{Ca}^{2+}$ Flux and Sensitivity to Ru360. Mol. Cell 2018, 72, 778-785. [CrossRef] [PubMed]

38. Paillard, M.; Csordás, G.; Szanda, G.; Golenár, T.; Debattisti, V.; Bartok, A.; Wang, N.; Moffat, C.; Seifert, E.L.; Spät, A.; et al. Tissue-Specific Mitochondrial Decoding of Cytoplasmic Ca ${ }^{2+}$ Signals Is Controlled by the Stoichiometry of MICU1/2 and MCU. Cell Rep. 2017, 18, 2291-2300. [CrossRef]

39. Checchetto, V.; Szabò, I. MCU Regulation in Lipid Bilayer and Electrophysiological Recording; Humana: New York, NY, USA, 2019; pp. 59-63.

40. Raffaello, A.; De Stefani, D.; Sabbadin, D.; Teardo, E.; Merli, G.; Picard, A.; Checchetto, V.; Moro, S.; Szabò, I.; Rizzuto, R. The mitochondrial calcium uniporter is a multimer that can include a dominant-negative pore-forming subunit. EMBO J. 2013, 32, 2362-2376. [CrossRef] [PubMed]

41. Liu, J.C.; Liu, J.; Holmström, K.M.; Menazza, S.; Parks, R.J.; Fergusson, M.M.; Yu, Z.X.; Springer, D.A.; Halsey, C.; Liu, C.; et al. MICU1 Serves as a Molecular Gatekeeper to Prevent In Vivo Mitochondrial Calcium Overload. Cell Rep. 2016, 16, 1561-1573. [CrossRef]

42. Kamer, K.J.; Grabarek, Z.; Mootha, V.K. High-affinity cooperative Ca ${ }^{2+}$ binding by MICU 1-MICU 2 serves as an on-off switch for the uniporter. EMBO Rep. 2017, 18, 1397-1411. [CrossRef]

43. Kamer, K.J.; Sancak, Y.; Fomina, Y.; Meisel, J.D.; Chaudhuri, D.; Grabarek, Z.; Mootha, V.K. MICU1 imparts the mitochondrial uniporter with the ability to discriminate between $\mathrm{Ca}^{2+}$ and $\mathrm{Mn}^{2+}$. Proc. Natl. Acad. Sci. USA 2018, 115, E7960-E7969. [CrossRef] 
44. Wettmarshausen, J.; Goh, V.; Huang, K.T.; Arduino, D.M.; Tripathi, U.; Leimpek, A.; Cheng, Y.; Pittis, A.A.; Gabaldón, T.; Mokranjac, D.; et al. MICU1 Confers Protection from MCU-Dependent Manganese Toxicity. Cell Rep. 2018, 25, 1425-1435. [CrossRef] [PubMed]

45. Tufi, R.; Gleeson, T.P.; von Stockum, S.; Hewitt, V.L.; Lee, J.J.; Terriente-Felix, A.; Sanchez-Martinez, A.; Ziviani, E.; Whitworth, A.J. Comprehensive Genetic Characterization of Mitochondrial $\mathrm{Ca}^{2+}$ Uniporter Components Reveals Their Different Physiological Requirements In Vivo. Cell Rep. 2019, 27, 1541-1550. [CrossRef] [PubMed]

46. Matteucci, A.; Patron, M.; Reane, D.V.; Gastaldello, S.; Amoroso, S.; Rizzuto, R.; Brini, M.; Raffaello, A.; Calì, T. Parkin-dependent regulation of the MCU complex component MICU1. Sci. Rep. 2018, 8, 14199. [CrossRef]

47. Vecellio Reane, D.; Vallese, F.; Checchetto, V.; Acquasaliente, L.; Butera, G.; De Filippis, V.; Szabò, I.; Zanotti, G.; Rizzuto, R.; Raffaello, A. A MICU1 Splice Variant Confers High Sensitivity to the Mitochondrial Ca ${ }^{2+}$ Uptake Machinery of Skeletal Muscle. Mol. Cell 2016, 64, 760-773. [CrossRef] [PubMed]

48. Kamer, K.J.; Jiang, W.; Kaushik, V.K.; Mootha, V.K.; Grabarek, Z. Crystal structure of MICU2 and comparison with MICU1 reveal insights into the uniporter gating mechanism. Proc. Natl. Acad. Sci. USA 2019, 116, 3546-3555. [CrossRef] [PubMed]

49. Xing, Y.; Wang, M.; Wang, J.; Nie, Z.; Wu, G.; Yang, X.; Shen, Y. Dimerization of MICU Proteins Controls Ca ${ }^{2+}$ Influx through the Mitochondrial $\mathrm{Ca}^{2+}$ Uniporter. Cell Rep. 2019, 26, 1203-1212. [CrossRef] [PubMed]

50. Payne, R.; Hoff, H.; Roskowski, A.; Foskett, J.K. MICU2 Restricts Spatial Crosstalk between InsP3R and MCU Channels by Regulating Threshold and Gain of MICU1-Mediated Inhibition and Activation of MCU. Cell Rep. 2017, 21, 3141-3154. [CrossRef] [PubMed]

51. Bick, A.G.; Wakimoto, H.; Kamer, K.J.; Sancak, Y.; Goldberger, O.; Axelsson, A.; DeLaughter, D.M.; Gorham, J.M.; Mootha, V.K.; Seidman, J.G.; et al. Cardiovascular homeostasis dependence on MICU2, a regulatory subunit of the mitochondrial calcium uniporter. Proc. Natl. Acad. Sci. USA 2017, 114, E9096-E9104. [CrossRef]

52. Shamseldin, H.E.; Alasmari, A.; Salih, M.A.; Samman, M.M.; Mian, S.A.; Alshidi, T.; Ibrahim, N.; Hashem, M.; Faqeih, E.; Al-Mohanna, F.; et al. A null mutation in MICU2 causes abnormal mitochondrial calcium homeostasis and a severe neurodevelopmental disorder. Brain 2017, 140, 2806-2813. [CrossRef]

53. Plovanich, M.; Bogorad, R.L.; Sancak, Y.; Kamer, K.J.; Strittmatter, L.; Li, A.A.; Girgis, H.S.; Kuchimanchi, S.; De Groot, J.; Speciner, L.; et al. MICU2, a paralog of MICU1, resides within the mitochondrial uniporter complex to regulate calcium handling. PLoS ONE 2013, 8, e55785. [CrossRef]

54. Patron, M.; Granatiero, V.; Espino, J.; Rizzuto, R.; De Stefani, D. MICU3 is a tissue-specific enhancer of mitochondrial calcium uptake. Cell Death Differ. 2019, 26, 179-195. [CrossRef] [PubMed]

55. Yamamoto, T.; Yamagoshi, R.; Harada, K.; Kawano, M.; Minami, N.; Ido, Y.; Kuwahara, K.; Fujita, A.; Ozono, M.; Watanabe, A.; et al. Analysis of the structure and function of EMRE in a yeast expression system. Biochim. Biophys. Acta Bioenerg. 2016, 1857, 831-839. [CrossRef] [PubMed]

56. Tsai, M.F.; Phillips, C.B.; Ranaghan, M.; Tsai, C.W.; Wu, Y.; Williams, C.; Miller, C. Dual functions of a small regulatory subunit in the mitochondrial calcium uniporter complex. Elife 2016, 5, e15545. [CrossRef] [PubMed]

57. Vais, H.; Mallilankaraman, K.; Mak, D.O.D.; Hoff, H.; Payne, R.; Tanis, J.E.; Foskett, J.K. EMRE Is a Matrix $\mathrm{Ca}\left({ }^{2+}\right)$ Sensor that Governs Gatekeeping of the Mitochondrial Ca $\left({ }^{2+}\right)$ Uniporter. Cell Rep. 2016, 14, 403-410. [CrossRef] [PubMed]

58. Holmström, K.M.; Pan, X.; Liu, J.C.; Menazza, S.; Liu, J.; Nguyen, T.T.; Pan, H.; Parks, R.J.; Anderson, S.; Noguchi, A.; et al. Assessment of cardiac function in mice lacking the mitochondrial calcium uniporter. J. Mol. Cell. Cardiol. 2015, 85, 178-182. [CrossRef]

59. Tomar, D.; Dong, Z.; Shanmughapriya, S.; Koch, D.A.; Thomas, T.; Hoffman, N.E.; Timbalia, S.A.; Goldman, S.J.; Breves, S.L.; Corbally, D.P.; et al. MCUR1 Is a Scaffold Factor for the MCU Complex Function and Promotes Mitochondrial Bioenergetics. Cell Rep. 2016, 15, 1673-1685. [CrossRef] [PubMed]

60. Adlakha, J.; Karamichali, I.; Sangwallek, J.; Deiss, S.; Bär, K.; Coles, M.; Hartmann, M.D.; Lupas, A.N.; Hernandez Alvarez, B. Characterization of MCU-Binding Proteins MCUR1 and CCDC90B-Representatives of a Protein Family Conserved in Prokaryotes and Eukaryotic Organelles. Structure 2019, 27, 464-475. [CrossRef] 
61. Chaudhuri, D.; Artiga, D.J.; Abiria, S.A.; Clapham, D.E. Mitochondrial calcium uniporter regulator 1 (MCUR1) regulates the calcium threshold for the mitochondrial permeability transition. Proc. Natl. Acad. Sci. USA 2016, 113, E1872-E1880. [CrossRef]

62. Jin, M.; Wang, J.; Ji, X.; Cao, H.; Zhu, J.; Chen, Y.; Yang, J.; Zhao, Z.; Ren, T.; Xing, J. MCUR1 facilitates epithelial-mesenchymal transition and metastasis via the mitochondrial calcium dependent ROS/Nrf2/Notch pathway in hepatocellular carcinoma. J. Exp. Clin. Cancer Res. 2019, 38, 136. [CrossRef]

63. Nemani, N.; Shanmughapriya, S.; Madesh, M. Molecular regulation of MCU: Implications in physiology and disease. Cell Calcium 2018, 74, 86-93. [CrossRef]

64. Shanmughapriya, S.; Rajan, S.; Hoffman, N.E.; Zhang, X.; Guo, S.; Kolesar, J.E.; Hines, K.J.; Ragheb, J.; Jog, N.R.; Caricchio, R.; et al. $\mathrm{Ca}^{2+}$ signals regulate mitochondrial metabolism by stimulating CREB-mediated expression of the mitochondrial $\mathrm{Ca}^{2+}$ uniporter gene MCU. Sci. Signal. 2015, 8, ra23. [CrossRef]

65. Shanmughapriya, S.; Tomar, D.; Dong, Z.; Slovik, K.J.; Nemani, N.; Natarajaseenivasan, K.; Carvalho, E.; Lu, C.; Corrigan, K.; Garikipati, V.N.S.; et al. FOXD1-dependent MICU1 expression regulates mitochondrial activity and cell differentiation. Nat. Commun. 2018, 9, 3449. [CrossRef] [PubMed]

66. Jaquenod De Giusti, C.; Roman, B.; Das, S. The Influence of MicroRNAs on Mitochondrial Calcium. Front. Physiol. 2018, 9, 1291. [CrossRef]

67. Yu, C.; Wang, Y.; Peng, J.; Shen, Q.; Chen, M.; Tang, W.; Li, X.; Cai, C.; Wang, B.; Cai, S.; et al. Mitochondrial calcium uniporter as a target of microRNA-340 and promoter of metastasis via enhancing the Warburg effect. Oncotarget 2017, 8, 83831-83844. [CrossRef] [PubMed]

68. Marchi, S.; Lupini, L.; Patergnani, S.; Rimessi, A.; Missiroli, S.; Bonora, M.; Bononi, A.; Corrà, F.; Giorgi, C.; De Marchi, E.; et al. Downregulation of the Mitochondrial Calcium Uniporter by Cancer-Related miR-25. Curr. Biol. 2013, 23, 58-63. [CrossRef] [PubMed]

69. Hong, Z.; Chen, K.H.; DasGupta, A.; Potus, F.; Dunham-Snary, K.; Bonnet, S.; Tian, L.; Fu, J.; Breuils-Bonnet, S.; Provencher, S.; et al. MicroRNA-138 and MicroRNA-25 Down-regulate Mitochondrial Calcium Uniporter, Causing the Pulmonary Arterial Hypertension Cancer Phenotype. Am. J. Respir. Crit. Care Med. 2017, 195, 515-529. [CrossRef] [PubMed]

70. Boucherat, O.; Vitry, G.; Trinh, I.; Paulin, R.; Provencher, S.; Bonnet, S. The cancer theory of pulmonary arterial hypertension. Pulm. Circ. 2017, 7, 285-299. [CrossRef] [PubMed]

71. Pan, L.; Huang, B.J.; Ma, X.E.; Wang, S.Y.; Feng, J.; Lv, F.; Liu, Y.; Liu, Y.; Li, C.M.; Liang, D.D.; et al. MiR-25 Protects Cardiomyocytes against Oxidative Damage by Targeting the Mitochondrial Calcium Uniporter. Int. J. Mol. Sci. 2015, 16, 5420-5433. [CrossRef]

72. Zaglia, T.; Ceriotti, P.; Campo, A.; Borile, G.; Armani, A.; Carullo, P.; Prando, V.; Coppini, R.; Vida, V.; Stølen, T.O.; et al. Content of mitochondrial calcium uniporter (MCU) in cardiomyocytes is regulated by microRNA-1 in physiologic and pathologic hypertrophy. Proc. Natl. Acad. Sci. USA 2017, 114, E9006-E9015. [CrossRef]

73. Paiva, S.; Agbulut, O. MiRroring the Multiple Potentials of MicroRNAs in Acute Myocardial Infarction. Front. Cardiovasc. Med. 2017, 4, 73. [CrossRef]

74. Favaro, G.; Romanello, V.; Varanita, T.; Desbats, M.A.; Morbidoni, V.; Tezze, C.; Albiero, M.; Canato, M.; Gherardi, G.; De Stefani, D.; et al. DRP1-mediated mitochondrial shape controls calcium homeostasis and muscle mass. Nat. Commun. 2019, 10, 2576. [CrossRef] [PubMed]

75. Uchi, J.; Jhun, B.S.; Xu, S.; Hurst, S.; Raffaello, A.; Liu, X.; Yi, B.; Zhang, H.; Gross, P.; Mishra, J.; et al. Adrenergic Signaling Regulates Mitochondrial $\mathrm{Ca}^{2+}$ Uptake Through Pyk2-Dependent Tyrosine Phosphorylation of the Mitochondrial $\mathrm{Ca}^{2+}$ Uniporter. Antioxid. Redox Signal. 2014, 21, 863-879. [CrossRef] [PubMed]

76. Zhang, K.; Yan, J.; Wang, L.; Tian, X.; Zhang, T.; Guo, L.; Li, B.; Wang, W.; Liu, X. The Pyk2/MCU pathway in the rat middle cerebral artery occlusion model of ischemic stroke. Neurosci. Res. 2018, 131, 52-62. [CrossRef] [PubMed]

77. Nickel, A.G.; Kohlhaas, M.; Bertero, E.; Wilhelm, D.; Wagner, M.; Sequeira, V.; Kreusser, M.M.; Dewenter, M.; Kappl, R.; Hoth, M.; et al. CaMKII does not control mitochondrial $\mathrm{Ca}^{2+}$ uptake in cardiac myocytes. J. Physiol. 2019. [CrossRef] [PubMed]

78. Lee, Y.; Min, C.K.; Kim, T.G.; Song, H.K.; Lim, Y.; Kim, D.; Shin, K.; Kang, M.; Kang, J.Y.; Youn, H.S.; et al. Structure and function of the N-terminal domain of the human mitochondrial calcium uniporter. EMBO Rep. 2015, 16, 1318-1333. [CrossRef] [PubMed] 
79. Nguyen, E.K.; Koval, O.M.; Noble, P.; Broadhurst, K.; Allamargot, C.; Wu, M.; Strack, S.; Thiel, W.H.; Grumbach, I.M. CaMKII ( $\mathrm{Ca}^{2+} /$ Calmodulin-Dependent Kinase II) in Mitochondria of Smooth Muscle Cells Controls Mitochondrial Mobility, Migration, and Neointima Formation. Arterioscler. Thromb. Vasc. Biol. 2018, 38, 1333-1345. [CrossRef]

80. Zhao, H.; Li, T.; Wang, K.; Zhao, F.; Chen, J.; Xu, G.; Zhao, J.; Li, T.; Chen, L.; Li, L.; et al. AMPK-mediated activation of MCU stimulates mitochondrial $\mathrm{Ca}^{2+}$ entry to promote mitotic progression. Nat. Cell Biol. 2019, 21, 476-486. [CrossRef]

81. Zeng, F.; Chen, X.; Cui, W.; Wen, W.; Lu, F.; Sun, X.; Ma, D.; Yuan, Y.; Li, Z.; Hou, N.; et al. RIPK1 Binds MCU to Mediate Induction of Mitochondrial $\mathrm{Ca}^{2+}$ Uptake and Promotes Colorectal Oncogenesis. Cancer Res. 2018, 78, 2876-2885. [CrossRef]

82. Marchi, S.; Corricelli, M.; Branchini, A.; Vitto, V.A.M.; Missiroli, S.; Morciano, G.; Perrone, M.; Ferrarese, M.; Giorgi, C.; Pinotti, M.; et al. Akt-mediated phosphorylation of MICU1 regulates mitochondrial Ca ${ }^{2+}$ levels and tumor growth. EMBO J. 2019, 38, e99435. [CrossRef]

83. Madreiter-Sokolowski, C.T.; Klec, C.; Parichatikanond, W.; Stryeck, S.; Gottschalk, B.; Pulido, S.; Rost, R.; Eroglu, E.; Hofmann, N.A.; Bondarenko, A.I.; et al. PRMT1-mediated methylation of MICU1 determines the UCP2/3 dependency of mitochondrial $\mathrm{Ca}^{2+}$ uptake in immortalized cells. Nat. Commun. 2016, 7, 12897. [CrossRef]

84. Trenker, M.; Malli, R.; Fertschai, I.; Levak-Frank, S.; Graier, W.F. Uncoupling proteins 2 and 3 are fundamental for mitochondrial $\mathrm{Ca}^{2+}$ uniport. Nat. Cell Biol. 2007, 9, 445-452. [CrossRef] [PubMed]

85. Brookes, P.S.; Parker, N.; Buckingham, J.A.; Vidal-Puig, A.; Halestrap, A.P.; Gunter, T.E.; Nicholls, D.G.; Bernardi, P.; Lemasters, J.J.; Brand, M.D. UCPs-Unlikely calcium porters. Nat. Cell Biol. 2008, 10, 1235-1237. [CrossRef] [PubMed]

86. Motloch, L.J.; Larbig, R.; Gebing, T.; Reda, S.; Schwaiger, A.; Leitner, J.; Wolny, M.; Eckardt, L.; Hoppe, U.C. By Regulating Mitochondrial Ca ${ }^{2+}-$ Uptake UCP2 Modulates Intracellular Ca ${ }^{2+}$. PLoS ONE 2016, 11, e0148359. [CrossRef] [PubMed]

87. Bondarenko, A.I.; Parichatikanond, W.; Madreiter, C.T.; Rost, R.; Waldeck-Weiermair, M.; Malli, R.; Graier, W.F. UCP2 modulates single-channel properties of a MCU-dependent $\mathrm{Ca}^{2+}$ inward current in mitochondria. Pflügers Arch. Eur. J. Physiol. 2015, 467, 2509-2518. [CrossRef] [PubMed]

88. Opalińska, M.; Jańska, H.; Opalińska, M.; Jańska, H. AAA Proteases: Guardians of Mitochondrial Function and Homeostasis. Cells 2018, 7, 163. [CrossRef] [PubMed]

89. Tsai, C.W.; Wu, Y.; Pao, P.C.; Phillips, C.B.; Williams, C.; Miller, C.; Ranaghan, M.; Tsai, M.F. Proteolytic control of the mitochondrial calcium uniporter complex. Proc. Natl. Acad. Sci. USA 2017, 114, 4388-4393. [CrossRef]

90. König, T.; Tröder, S.E.; Bakka, K.; Korwitz, A.; Richter-Dennerlein, R.; Lampe, P.A.; Patron, M.; Mühlmeister, M.; Guerrero-Castillo, S.; Brandt, U.; et al. The m-AAA Protease Associated with Neurodegeneration Limits MCU Activity in Mitochondria. Mol. Cell 2016, 64, 148-162. [CrossRef]

91. Hurst, S.; Baggett, A.; Csordas, G.; Sheu, S.S. SPG7 targets the m-AAA protease complex to process MCU for uniporter assembly, $\mathrm{Ca}^{2+}$ influx, and regulation of mPTP opening. J. Biol. Chem. 2019. [CrossRef]

92. Pareek, G.; Thomas, R.E.; Pallanck, L.J. Loss of the Drosophila m-AAA mitochondrial protease paraplegin results in mitochondrial dysfunction, shortened lifespan, and neuronal and muscular degeneration. Cell Death Dis. 2018, 9, 304. [CrossRef]

93. Bers, D.M. Cardiac excitation-contraction coupling. Nature 2002, 415, 198-205. [CrossRef]

94. Fieni, F.; Bae Lee, S.; Nung Jan, Y.; Kirichok, Y. ARTICLE Activity of the mitochondrial calcium uniporter varies greatly between tissues. Nat. Commun. 2012, 3, 1317. [CrossRef] [PubMed]

95. Kwong, J.Q.; Lu, X.; Correll, R.N.; Schwanekamp, J.A.; Vagnozzi, R.J.; Sargent, M.A.; York, A.J.; Zhang, J.; Bers, D.M.; Molkentin, J.D. The Mitochondrial Calcium Uniporter Selectively Matches Metabolic Output to Acute Contractile Stress in the Heart. Cell Rep. 2015, 12, 15-22. [CrossRef] [PubMed]

96. Luongo, T.S.; Lambert, J.P.; Yuan, A.; Zhang, X.; Gross, P.; Song, J.; Shanmughapriya, S.; Gao, E.; Jain, M.; Houser, S.R.; et al. The Mitochondrial Calcium Uniporter Matches Energetic Supply with Cardiac Workload during Stress and Modulates Permeability Transition. Cell Rep. 2015, 12, 23-34. [CrossRef] [PubMed]

97. De la Fuente, S.; Sheu, S.S. SR-mitochondria communication in adult cardiomyocytes: A close relationship where the $\mathrm{Ca}^{2+}$ has a lot to say. Arch. Biochem. Biophys. 2019, 663, 259-268. [CrossRef] 
98. Lu, X.; Ginsburg, K.S.; Kettlewell, S.; Bossuyt, J.; Smith, G.L.; Bers, D.M. Measuring local gradients of intramitochondrial $\left[\mathrm{Ca}\left({ }^{2+}\right)\right]$ in cardiac myocytes during sarcoplasmic reticulum $\mathrm{Ca}\left({ }^{2+}\right)$ release. Circ. Res. 2013, 112, 424-431. [CrossRef] [PubMed]

99. De La Fuente, S.; Fernandez-Sanz, C.; Vail, C.; Agra, E.J.; Holmstrom, K.; Sun, J.; Mishra, J.; Williams, D.; Finkel, T.; Murphy, E.; et al. Strategic Positioning and Biased Activity of the Mitochondrial Calcium Uniporter in Cardiac Muscle. J. Biol. Chem. 2016, 291, 23343-23362. [CrossRef] [PubMed]

100. De La Fuente, S.; Lambert, J.P.; Nichtova, Z.; Fernandez Sanz, C.; Elrod, J.W.; Sheu, S.S.; Csordás, G. Spatial Separation of Mitochondrial Calcium Uptake and Extrusion for Energy-Efficient Mitochondrial Calcium Signaling in the Heart. Cell Rep. 2018, 24, 3099-3107. [CrossRef] [PubMed]

101. Bernardo, B.C.; Weeks, K.L.; Pretorius, L.; McMullen, J.R. Molecular distinction between physiological and pathological cardiac hypertrophy: Experimental findings and therapeutic strategies. Pharmacol. Ther. 2010, 128, 191-227. [CrossRef]

102. Piquereau, J.; Ventura-Clapier, R. Maturation of Cardiac Energy Metabolism during Perinatal Development. Front. Physiol. 2018, 9, 959. [CrossRef]

103. Yu, Z.; Chen, R.; Li, M.; Yu, Y.; Liang, Y.; Han, F.; Qin, S.; Chen, X.; Su, Y.; Ge, J. Mitochondrial calcium uniporter inhibition provides cardioprotection in pressure overload-induced heart failure through autophagy enhancement. Int. J. Cardiol. 2018, 271, 161-168. [CrossRef]

104. Wong, C.X.; Brown, A.; Lau, D.H.; Chugh, S.S.; Albert, C.M.; Kalman, J.M.; Sanders, P. Epidemiology of Sudden Cardiac Death: Global and Regional Perspectives. Heart Lung Circ. 2019, 28, 6-14. [CrossRef] [PubMed]

105. Di Diego, J.M.; Antzelevitch, C. Ischemic ventricular arrhythmias: Experimental models and their clinical relevance. Heart Rhythm 2011, 8, 1963-1968. [CrossRef] [PubMed]

106. Baumeister, P.; Quinn, T.A. Altered Calcium Handling and Ventricular Arrhythmias in Acute Ischemia. Clin. Med. Insights Cardiol. 2016, 10, 61. [CrossRef] [PubMed]

107. Xie, A.; Zhou, A.; Liu, H.; Shi, G.; Liu, M.; Boheler, K.R.; Dudley, S.C. Mitochondrial Ca ${ }^{2+}$ flux modulates spontaneous electrical activity in ventricular cardiomyocytes. PLoS ONE 2018, 13, e0200448. [CrossRef] [PubMed]

108. Hamilton, S.; Terentyeva, R.; Kim, T.Y.; Bronk, P.; Clements, R.T.; O-Uchi, J.; Csordás, G.; Choi, B.R.; Terentyev, D. Pharmacological Modulation of Mitochondrial $\mathrm{Ca}^{2+}$ Content Regulates Sarcoplasmic Reticulum $\mathrm{Ca}^{2+}$ Release via Oxidation of the Ryanodine Receptor by Mitochondria-Derived Reactive Oxygen Species. Front. Physiol. 2018, 9, 1831. [CrossRef]

109. Xie, A.; Song, Z.; Liu, H.; Zhou, A.; Shi, G.; Wang, Q.; Gu, L.; Liu, M.; Xie, L.H.; Qu, Z.; et al. Mitochondrial $\mathrm{Ca}^{2+}$ Influx Contributes to Arrhythmic Risk in Nonischemic Cardiomyopathy. J. Am. Heart Assoc. 2018, 7, e007805. [CrossRef]

110. Schweitzer, M.K.; Wilting, F.; Sedej, S.; Dreizehnter, L.; Dupper, N.J.; Tian, Q.; Moretti, A.; My, I.; Kwon, O.;

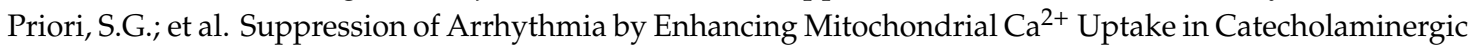
Ventricular Tachycardia Models. JACC Basic Transl. Sci. 2017, 2, 737-747. [CrossRef]

111. Larbig, R.; Reda, S.; Paar, V.; Trost, A.; Leitner, J.; Weichselbaumer, S.; Motloch, K.A.; Wernly, B.; Arrer, A.; Strauss, B.; et al. Through modulation of cardiac $\mathrm{Ca}^{2+}$ handling, UCP2 affects cardiac electrophysiology and influences the susceptibility for $\mathrm{Ca}^{2+}$-mediated arrhythmias. Exp. Physiol. 2017, 102, 650-662. [CrossRef]

112. Matsunaga, T.; Gu, N.; Yamazaki, H.; Tsuda, M.; Adachi, T.; Yasuda, K.; Moritani, T.; Tsuda, K.; Nonaka, M.; Nishiyama, T. Association of UCP2 and UCP3 polymorphisms with heart rate variability in Japanese men. J. Hypertens. 2009, 27, 305-313. [CrossRef]

113. Lang, D.; Glukhov, A.V.; Efimova, T.; Efimov, I.R. Role of Pyk2 in cardiac arrhythmogenesis. Am. J. Physiol. Heart Circ. Physiol. 2011, 301, H975-H983. [CrossRef]

114. Ezeani, M.; Elom, S. Necessity to evaluate PI3K/Akt signalling pathway in proarrhythmia. Open Heart 2017, 4, e000596. [CrossRef] [PubMed]

115. Quinaglia, T.; Jerosch-Herold, M.; Coelho-Filho, O.R. State-of-the-Art Quantitative Assessment of Myocardial Ischemia by Stress Perfusion Cardiac Magnetic Resonance. Magn. Reson. Imaging Clin. 2019, 27, 491-505. [CrossRef] [PubMed]

116. Boyman, L.; Williams, G.S.B.; Lederer, W.J. Mitochondrial Calcium and Ischemia: Reperfusion Injury in Heart. In Mitochondria and Cell Death; Springer: New York, NY, USA, 2016; pp. 17-43. 
117. Altamimi, T.R.; Karwi, Q.G.; Uddin, G.M.; Fukushima, A.; Kwong, J.Q.; Molkentin, J.D.; Lopaschuk, G.D. Cardiac-specific deficiency of the mitochondrial calcium uniporter augments fatty acid oxidation and functional reserve. J. Mol. Cell. Cardiol. 2019, 127, 223-231. [CrossRef] [PubMed]

118. Oropeza-Almazán, Y.; Vázquez-Garza, E.; Chapoy-Villanueva, H.; Torre-Amione, G.; García-Rivas, G. Small Interfering RNA Targeting Mitochondrial Calcium Uniporter Improves Cardiomyocyte Cell Viability in Hypoxia/Reoxygenation Injury by Reducing Calcium Overload. Oxidative Med. Cell. Longev. 2017, 2017, 5750897. [CrossRef] [PubMed]

119. Rasmussen, T.P.; Wu, Y.; Joiner, M.A.; Koval, O.M.; Wilson, N.R.; Luczak, E.D.; Wang, Q.; Chen, B.; Gao, Z.; Zhu, Z.; et al. Inhibition of MCU forces extramitochondrial adaptations governing physiological and pathological stress responses in heart. Proc. Natl. Acad. Sci. USA 2015, 112, 9129-9134. [CrossRef] [PubMed]

120. Parks, R.J.; Menazza, S.; Holmström, K.M.; Amanakis, G.; Fergusson, M.; Ma, H.; Aponte, A.M.; Bernardi, P.; Finkel, T.; Murphy, E. Cyclophilin D-mediated regulation of the permeability transition pore is altered in mice lacking the mitochondrial calcium uniporter. Cardiovasc. Res. 2019, 115, 385-394. [CrossRef]

121. Xue, Q.; Pei, H.; Liu, Q.; Zhao, M.; Sun, J.; Gao, E.; Ma, X.; Tao, L. MICU1 protects against myocardial ischemia/reperfusion injury and its control by the importer receptor Tom70. Cell Death Dis. 2017, 8, e2923. [CrossRef]

122. Kohlhaas, M.; Nickel, A.G.; Maack, C. Mitochondrial energetics and calcium coupling in the heart. J. Physiol. 2017, 595, 3753-3763. [CrossRef]

123. Zhou, B.; Tian, R. Mitochondrial dysfunction in pathophysiology of heart failure. J. Clin. Investig. 2018, 128, 3716-3726. [CrossRef]

124. Yu, Z.; Gong, X.; Yu, Y.; Li, M.; Liang, Y.; Qin, S.; Fulati, Z.; Zhou, N.; Shu, X.; Nie, Z.; et al. The mechanical effects of CRT promoting autophagy via mitochondrial calcium uniporter down-regulation and mitochondrial dynamics alteration. J. Cell. Mol. Med. 2019, 23, 3833-3842. [CrossRef]

125. Cho, H.M.; Ryu, J.R.; Jo, Y.; Seo, T.W.; Choi, Y.N.; Kim, J.H.; Chung, J.M.; Cho, B.; Kang, H.C.; Yu, S.W.; et al. Drp1-Zip1 Interaction Regulates Mitochondrial Quality Surveillance System. Mol. Cell 2019, 73, 364-376. [CrossRef] [PubMed]

126. Luo, S.; Chen, Y.; He, R.; Shi, Y.; Su, L. Rescuing infusion of miRNA-1 prevents cardiac remodeling in a heart-selective miRNA deficient mouse. Biochem. Biophys. Res. Commun. 2018, 495, 607-613. [CrossRef] [PubMed]

127. Sygitowicz, G.; Polska, K.; Tomaniak, M.; Błaszczyk, O.; Kołtowski, Ł.; Puchta, D.; Malesa, K.; Kochanowski, J.; Sitkiewicz, D.; Filipiak, K.J. miR-1, miR-21, and galectin-3 in hypertensive patients with symptomatic heart failure and left ventricular hypertrophy. Kardiol. Pol. 2018, 76, 1009-1011.

128. Luongo, T.S.; Lambert, J.P.; Gross, P.; Nwokedi, M.; Lombardi, A.A.; Shanmughapriya, S.; Carpenter, A.C.; Kolmetzky, D.; Gao, E.; van Berlo, J.H.; et al. The mitochondrial $\mathrm{Na}+/ \mathrm{Ca}^{2+}$ exchanger is essential for $\mathrm{Ca}^{2+}$ homeostasis and viability. Nature 2017, 545, 93-97. [CrossRef] [PubMed]

129. Frontera, W.R.; Ochala, J. Skeletal Muscle: A Brief Review of Structure and Function. Calcif. Tissue Int. 2015, 96, 183-195. [CrossRef]

130. Mammucari, C.; Raffaello, A.; Vecellio Reane, D.; Gherardi, G.; De Mario, A.; Rizzuto, R. Mitochondrial calcium uptake in organ physiology: From molecular mechanism to animal models. Pflugers Arch. 2018, 470, 1165-1179. [CrossRef] [PubMed]

131. Mammucari, C.; Gherardi, G.; Zamparo, I.; Raffaello, A.; Boncompagni, S.; Chemello, F.; Cagnin, S.; Braga, A.; Zanin, S.; Pallafacchina, G.; et al. The Mitochondrial Calcium Uniporter Controls Skeletal Muscle Trophism In Vivo. Cell Rep. 2015, 10, 1269-1279. [CrossRef]

132. Gherardi, G.; Nogara, L.; Ciciliot, S.; Fadini, G.P.; Blaauw, B.; Braghetta, P.; Bonaldo, P.; De Stefani, D.; Rizzuto, R.; Mammucari, C. Loss of mitochondrial calcium uniporter rewires skeletal muscle metabolism and substrate preference. Cell Death Differ. 2019, 26, 362-381. [CrossRef]

133. Pan, X.; Liu, J.; Nguyen, T.; Liu, C.; Sun, J.; Teng, Y.; Fergusson, M.M.; Rovira, I.I.; Allen, M.; Springer, D.A.; et al. The physiological role of mitochondrial calcium revealed by mice lacking the mitochondrial calcium uniporter. Nat. Cell Biol. 2013, 15, 1464-1472. [CrossRef]

134. Kwong, J.Q.; Huo, J.; Bround, M.J.; Boyer, J.G.; Schwanekamp, J.A.; Ghazal, N.; Maxwell, J.T.; Jang, Y.C.; Khuchua, Z.; Shi, K.; et al. The mitochondrial calcium uniporter underlies metabolic fuel preference in skeletal muscle. JCI Insight 2018, 3. [CrossRef] 
135. Logan, C.V.; Szabadkai, G.; Sharpe, J.A.; Parry, D.A.; Torelli, S.; Childs, A.M.; Kriek, M.; Phadke, R.; Johnson, C.A.; Roberts, N.Y.; et al. Loss-of-function mutations in MICU1 cause a brain and muscle disorder linked to primary alterations in mitochondrial calcium signaling. Nat. Genet. 2014, 46, 188-193. [CrossRef] [PubMed]

136. Bhosale, G.; Sharpe, J.A.; Koh, A.; Kouli, A.; Szabadkai, G.; Duchen, M.R. Pathological consequences of MICU1 mutations on mitochondrial calcium signalling and bioenergetics. Biochim. Biophys. Acta Mol. Cell Res. 2017, 1864, 1009-1017. [CrossRef] [PubMed]

137. Lewis-Smith, D.; Kamer, K.J.; Griffin, H.; Childs, A.M.; Pysden, K.; Titov, D.; Duff, J.; Pyle, A.; Taylor, R.W.; Yu-Wai-Man, P.; et al. Homozygous deletion in MICU1 presenting with fatigue and lethargy in childhood. Neurol. Genet. 2016, 2, e59. [CrossRef] [PubMed]

138. Musa, S.; Eyaid, W.; Kamer, K.; Ali, R.; Al-Mureikhi, M.; Shahbeck, N.; Al Mesaifri, F.; Makhseed, N.; Mohamed, Z.; AlShehhi, W.A.; et al. A Middle Eastern Founder Mutation Expands the Genotypic and Phenotypic Spectrum of Mitochondrial MICU1 Deficiency: A Report of 13 Patients. JIMD Rep. 2019, 43, 79-83. [PubMed]

139. Lek, M.; Karczewski, K.J.; Minikel, E.V.; Samocha, K.E.; Banks, E.; Fennell, T.; O’Donnell-Luria, A.H.; Ware, J.S.; Hill, A.J.; Cummings, B.B.; et al. Analysis of protein-coding genetic variation in 60,706 humans. Nature 2016, 536, 285-291. [CrossRef] [PubMed]

140. Horn, A.; Van der Meulen, J.H.; Defour, A.; Hogarth, M.; Sreetama, S.C.; Reed, A.; Scheffer, L.; Chandel, N.S.; Jaiswal, J.K. Mitochondrial redox signaling enables repair of injured skeletal muscle cells. Sci. Signal. 2017, 10, eaaj1978. [CrossRef]

141. Zampieri, S.; Mammucari, C.; Romanello, V.; Barberi, L.; Pietrangelo, L.; Fusella, A.; Mosole, S.; Gherardi, G.; Höfer, C.; Löfler, S.; et al. Physical exercise in aging human skeletal muscle increases mitochondrial calcium uniporter expression levels and affects mitochondria dynamics. Physiol. Rep. 2016, 4, e13005. [CrossRef]

142. Touyz, R.M.; Alves-Lopes, R.; Rios, F.J.; Camargo, L.L.; Anagnostopoulou, A.; Arner, A.; Montezano, A.C. Vascular smooth muscle contraction in hypertension. Cardiovasc. Res. 2018, 114, 529-539. [CrossRef]

143. Kannurpatti, S.S.; Biswal, B.B. Mitochondrial $\mathrm{Ca}^{2+}$ uniporter blockers influence activation-induced CBF response in the rat somatosensory cortex. J. Cereb. Blood Flow Metab. 2008, 28, 772-785. [CrossRef]

144. Grossi, M.; Bhattachariya, A.; Nordström, I.; Turczyńska, K.M.; Svensson, D.; Albinsson, S.; Nilsson, B.O.; Hellstrand, P. Pyk2 inhibition promotes contractile differentiation in arterial smooth muscle. J. Cell. Physiol. 2017, 232, 3088-3102. [CrossRef]

145. Chen, X.; Zhang, Y.; Xu, B.; Cai, Z.; Wang, L.; Tian, J.; Liu, Y.; Li, Y. The mitochondrial calcium uniporter is involved in mitochondrial calcium cycle dysfunction: Underlying mechanism of hypertension associated with mitochondrial tRNA Ile A4263G mutation. Int. J. Biochem. Cell Biol. 2016, 78, 307-314. [CrossRef] [PubMed]

146. Pan, S.; Conaway, S.; Deshpande, D.A. Mitochondrial regulation of airway smooth muscle functions in health and pulmonary diseases. Arch. Biochem. Biophys. 2019, 663, 109-119. [CrossRef] [PubMed]

147. Delmotte, P.; Yang, B.; Thompson, M.A.; Pabelick, C.M.; Prakash, Y.S.; Sieck, G.C. Inflammation alters regional mitochondrial $\mathrm{Ca}^{2+}$ in human airway smooth muscle cells. Am. J. Physiol. Physiol. 2012, 303, C244-C256. [CrossRef] [PubMed]

148. Vishnyakova, P.A.; Tarasova, N.V.; Volodina, M.A.; Tsvirkun, D.V.; Sukhanova, I.A.; Kurchakova, T.A.; Kan, N.E.; Medzidova, M.K.; Sukhikh, G.T.; Vysokikh, M.Y. Gestation age-associated dynamics of mitochondrial calcium uniporter subunits expression in feto-maternal complex at term and preterm delivery. Sci. Rep. 2019, 9, 5501. [CrossRef] [PubMed]

149. Kamer, K.J.; Mootha, V.K. The molecular era of the mitochondrial calcium uniporter. Nat. Rev. Mol. Cell Biol. 2015, 16, 545-553. [CrossRef] [PubMed]

150. Woods, J.J.; Nemani, N.; Shanmughapriya, S.; Kumar, A.; Zhang, M.; Nathan, S.R.; Thomas, M.; Carvalho, E.; Ramachandran, K.; Srikantan, S.; et al. A Selective and Cell-Permeable Mitochondrial Calcium Uniporter (MCU) Inhibitor Preserves Mitochondrial Bioenergetics after Hypoxia/Reoxygenation Injury. ACS Cent. Sci. 2019, 5, 153-166. [CrossRef] [PubMed]

151. Kon, N.; Murakoshi, M.; Isobe, A.; Kagechika, K.; Miyoshi, N.; Nagayama, T. DS16570511 is a small-molecule inhibitor of the mitochondrial calcium uniporter. Cell Death Discov. 2017, 3, 17045. [CrossRef] [PubMed] 
152. Arduino, D.M.; Wettmarshausen, J.; Vais, H.; Navas-Navarro, P.; Cheng, Y.; Leimpek, A.; Ma, Z.; Delrio-Lorenzo, A.; Giordano, A.; Garcia-Perez, C.; et al. Systematic Identification of MCU Modulators by Orthogonal Interspecies Chemical Screening. Mol. Cell 2017, 67, 711-723. [CrossRef]

153. Imran, M.; Salehi, B.; Sharifi-Rad, J.; Aslam Gondal, T.; Saeed, F.; Imran, A.; Shahbaz, M.; Tsouh Fokou, P.V.; Umair Arshad, M.; Khan, H.; et al. Kaempferol: A Key Emphasis to Its Anticancer Potential. Molecules 2019, 24, 2277. [CrossRef]

154. Imran, M.; Rauf, A.; Shah, Z.A.; Saeed, F.; Imran, A.; Arshad, M.U.; Ahmad, B.; Bawazeer, S.; Atif, M.; Peters, D.G.; et al. Chemo-preventive and therapeutic effect of the dietary flavonoid kaempferol: A comprehensive review. Phytother. Res. 2019, 33, 263-275. [CrossRef]

(C) 2019 by the authors. Licensee MDPI, Basel, Switzerland. This article is an open access article distributed under the terms and conditions of the Creative Commons Attribution (CC BY) license (http://creativecommons.org/licenses/by/4.0/). 